\title{
Influence of benthic and pelagic environmental factors on the distribution of dinoflagellate cysts in surface sediments along the Swedish west coast
}

\author{
Anna Godhe*, Melissa R. McQuoid \\ Department of Marine Ecology, Marine Botany, Göteborg University, PO Box 461, 40530 Göteborg, Sweden
}

\begin{abstract}
Abundance and frequency of dinoflagellate cysts in 19 surface sediment samples from the northern part of the Swedish west coast has been related to physical and chemical characters of the sediment, hydrography of the overlying water column, and plankton species data from the area.

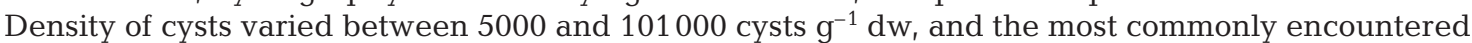
species were Lingulodinium polyedrum and Protoceratium reticulatum. In all, 46 environmental variables were tested for their relation to dinoflagellate cyst densities, proportion of autotrophic and heterotrophic taxa, and individual species distribution and frequency. The outcomes of multivariate analyses, projection to latent structures (PLS) and canonical correspondence analysis (CCA) were consistent with each other and the actual cyst count. The density of the total cyst assemblage (>90\% autotrophic taxa) was primarily related to surface temperature, macronutrients, and inversely to phytoplankton competitors, such as diatoms. The abundance of heterotrophic taxa was governed by the preferences of their prey, i.e. diatom-favourable conditions, and, in most cases, higher proportions of heterotrophic taxa were found at well-mixed sites. Some possible effects of anthropogenic contaminants were also noted. Several taxa showed distinct distribution patterns with respect to the environmental variables. A discrepancy between the species constituting the planktonic and the benthic community was revealed when data from 6 yr of plankton monitoring was compared to the data on distribution of dinoflagellate cysts. In particular, cyst-forming species were only a minor part of the plankton, suggesting that these dinoflagellates spend much of their life in the sediments.
\end{abstract}

KEY WORDS: Cysts · Dinoflagellate · Dinophyceae · Surface sediment • CCA · PLS . Environmental factors

\section{INTRODUCTION}

Ten percent of marine dinoflagellate species are known to produce benthic cysts (Dale 1983). Dinoflagellate cysts are initiated by sexual fusion of 2 compatible gametes. The resulting zygote loses its mobility, encysts, and sinks to the sea floor where it can survive in the sediment for several years (Lewis et al. 1999, McQuoid et al. 2002). After a period of dormancy in the sediment, the cysts may germinate and return to the water column. If the external conditions are favourable, the germinated cells can seed a planktonic population. Thus, cysts on the sea floor constitute potential seed banks that can be important to phytoplankton bloom dynamics. The cyst-rich sediments also provide a historical archive, since they are formed from the planktonic flora of the region, and they manifest both the species contribution and the relative frequency of cyst-forming species. Several dinoflagellate species are difficult to preserve or identify in their planktonic form. Fortunately, cyst surveys have extended the list of species known from several areas by identifying cyst counterparts in surface sediments (e.g. Ellegaard et al. 1994, Nehring 1994, Matsuoka 1999, Godhe et al. 2001). This is particularly true for gymnodinoid dinoflagellates that do not preserve well in fixed samples (Takayama et al. 1998). 
If conditions are favourable, dinoflagellate populations can form blooms. Moreover, some dinoflagellates are known to produce toxins, and blooms of these can devastate aquaculture enterprises, recreational areas, and regional economies (Hallegraeff 1995). The development of early warning systems to reduce deleterious effects of these blooms depends on our understanding and monitoring of the oceanographic and meteorological settings that promote harmful algae. Thus, it is important to study plankton dynamics, cyst formation, and cell distribution in relation to environmental factors.

Dinoflagellate cyst distribution has been related to external environmental phenomena, hydrographic regime, or latitude. The interpretations available are both from sediment cores and from surface sediment samples (e.g. Wall et al. 1977, Versteegh 1994, Blanco 1995, Matsuoka 1999, Devillers \& de Vernal 2000). Some papers have investigated which environmental

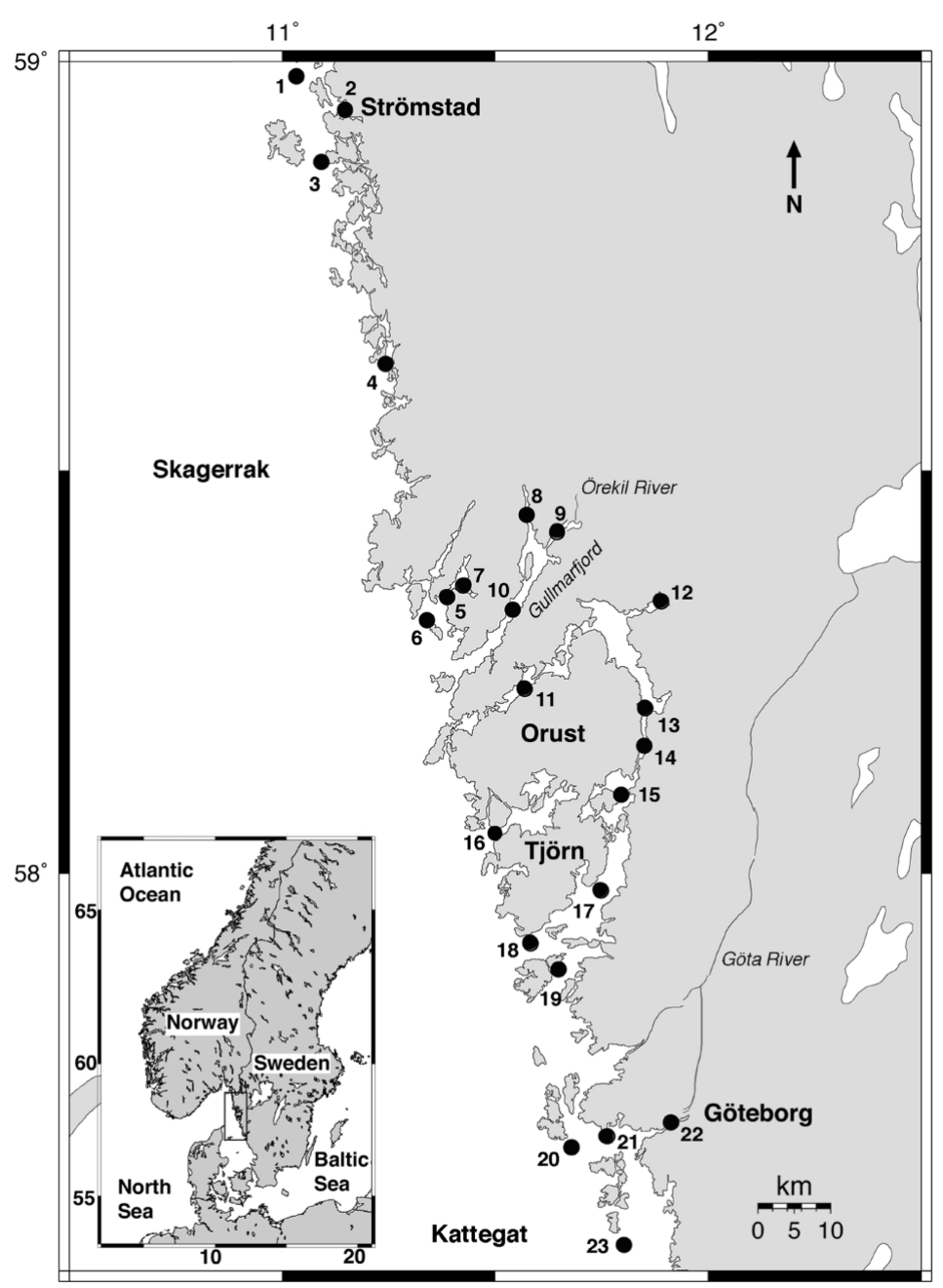

Fig. 1. Swedish west coast showing the location of sampling sites signal will promote changed proportions of autotrophic versus heterotrophic cyst assemblages, or protoperidinoid versus gonyaulacoid taxa-an important question, which we will also address in this study. In addition, some dinoflagellate taxa, such as Lingulodinium polyedrum, have been linked to cultural eutrophication (Dale et al. 1999).

In this study, we present a more comprehensive analysis of dinoflagellate cyst distribution in relation to both benthic and pelagic environmental factors. Here, species composition and density, from sediment samples analysed previously (Persson et al. 2000), are correlated with chemical and physical characters of those sediments and properties of the overlying water column by means of multivariate statistical analyses. In order to extract reliable trends from this large data set, 2 statistical methods are used. Results of the 2 methods are compared, and related to the actual counts of dinoflagellate cysts. Further, the cyst archive found in the sediment is compared to monitoring records of the planktonic flora in the region, as acquired from several years of monitoring.

\section{MATERIALS AND METHODS}

Study area. The study area (Fig. 1) is located in the Skagerrak and the northern Kattegat region on the Swedish west coast. Two major current systems affect the coastal area; the Baltic Current runs north, parallel to the coast, bringing low salinity surface water, whereas more saline water from the North Sea and Atlantic Ocean flows through the Skagerrak towards the Swedish coast in the Jutland Current. Hence, the coastal water is stratified in terms of salinity, and a pronounced halocline is present (Rodhe 1987, Lindahl 1995). The coastline has a variety of fjord systems. Gullmarfjord is the only true fjord with the mouth opening to the Skagerrak and freshwater from the Örekil River entering at the head. Normally, the water column in Gullmarfjord is stratified in 3 layers: a brackish surface layer that is a mixture of water originating from the Örekil River, the Baltic Sea, and the Skagerrak; a more saline layer of water that was formerly at the surface in the Skagerrak; and a fully saline deep layer of water from the Skagerrak and the North Sea (Svansson 1984). Pycnoclines at 10 to 20 and 50 to $60 \mathrm{~m}$ depth separate the 3 layers. Water deeper than $60 \mathrm{~m}$ is usually stagnant, but can be exchanged in the winter or early spring by means of deep-water upwelling from the Skagerrak. In contrast to Gullmarfjord, the fjord system between the mainland and the 
islands of Orust and Tjörn is an extensive open-ended series of interconnected fjords including Hakefjord, Halsefjord, Havstensfjord, Byfjord, and Koljöfjord. The southern end has a wide and relatively deep connection to the Skagerrak, whereas the northern end is constricted by shallow sills (Björk et al. 2000). Spring tidal ranges of about $0.3 \mathrm{~m}$ promote some exchange of surface water between the fjords and the Skagerrak, but the sills inhibit mixing of deep waters. As a result, deep waters of the inner fjords can become stagnant. Kosterfjord is another open-ended, but deep (maximum $250 \mathrm{~m}$ ) basin, protected from the Skagerrak by a chain of islands. Hypoxia does not normally occur in Kosterfjord since shallow sills do not inhibit water exchange. The Swedish west coast is subject to various effects from industrial development and waste management, especially in the Göteborg region, Gullmarfjord, and the Orust-Tjörn fjord system.

Sediment sampling, preparation, and microscopy. Surface sediment samples were collected by the Norwegian Institute for Water Research (NIVA) from 19 sites along the Swedish west coast in September 1995 (Fig. 1, Table 1). A box corer was used, and the top centimetre of sediment was collected with a flat spade. Samples were stored in the dark at $4^{\circ} \mathrm{C}$ until the sediment was analysed (within $1 \mathrm{yr}$ ). The samples were provided by courtesy of the Water Quality Association of the Bohus Coast (BVVF), which had ordered chemi$\mathrm{cal}$ and physical analyses on the same material.
For dry weight (dw) measurements, aliquots of $1 \mathrm{~g}$ in triplicate were weighed in ceramic vials. Sediment was dried to a constant weight at $105^{\circ} \mathrm{C}$ and weighed again after cooling in a desiccator. No compensation was made for salinity variation (20.4 to $34.8 \mathrm{PSU}$ ) when dw was estimated.

Samples for quantitative analysis were sonicated for $5 \mathrm{~min}$ and the 25 to $100 \mu \mathrm{m}$ fraction was collected by sieving (Persson et al. 2000). Samples were either examined directly or mounted in glycerine and counted and identified in a Zeiss Axiovert 135 inverted microscope and a Wild microscope. Living and dead cysts were recorded and identified according to literature listed in Persson et al. (2000, their Table II). A minimum of 250 cysts were identified and counted at each site.

Germination experiments. When microscopic species identification of the cysts was doubtful, germination experiments were conducted. Individual cysts were isolated with a micropipette and germinated in polystyrene NUNC 96 microwell plates. The media used was modified GPM (Loeblich 1975, Ellegaard et al. 1994). The cysts were germinated in a culturing chamber $\left(18^{\circ} \mathrm{C}, 12: 12 \mathrm{~h} \mathrm{~L}: \mathrm{D}, 80 \mu \mathrm{E} \mathrm{m}^{-2} \mathrm{~s}^{-1}\right)$. The resulting vegetative stages were stained with calcofluor (Fritz \& Triemer 1985) and identified from the literature (Drebes 1974, Dodge 1982, 1989, Tomas 1997) by the arrangement of thecal plates.

Phytoplankton composition. Monthly records of phytoplankton abundance were compiled by the

Table 1. Sampling locations (see also Fig. 1)

\begin{tabular}{|c|c|c|c|c|c|c|c|c|}
\hline Station & $\begin{array}{l}\text { Station } \\
\text { name }\end{array}$ & $\begin{array}{l}\text { Depth } \\
(\mathrm{m})\end{array}$ & (N) ${ }^{\text {Posi }}$ & ion & $\begin{array}{l}\text { Dinoflagellate } \\
\text { cyst }\end{array}$ & $\begin{array}{l}\text { Chemical and physical } \\
\text { analysis of sediment }\end{array}$ & Hydrography & Plankton \\
\hline 1 & Riksgränsen & 230 & $58^{\circ} 58.200$ & $11^{\circ} 03.200$ & & & & Yes \\
\hline 2 & Strömstad & 20 & $58^{\circ} 55.808$ & $11^{\circ} 09.954$ & Yes & Yes & & \\
\hline 3 & Kosterfjord & 94 & $58^{\circ} 52.098$ & $11^{\circ} 06.683$ & Yes & Yes & Yes & Yes \\
\hline 4 & Fjällbacka & 18 & $58^{\circ} 37.498$ & $11^{\circ} 15.566$ & Yes & Yes & & \\
\hline 5 & S 112 & 46 & $58^{\circ} 20.564$ & $11^{\circ} 24.065$ & Yes & Yes & Yes & \\
\hline 6 & S 316 & 37 & $58^{\circ} 18.912$ & $11^{\circ} 21.215$ & Yes & Yes & & \\
\hline 7 & S 141 & 21 & $58^{\circ} 21.441$ & $11^{\circ} 26.269$ & Yes & Yes & & \\
\hline 8 & Färlevsfjord & 15 & $58^{\circ} 26.589$ & $11^{\circ} 35.037$ & Yes & Yes & & \\
\hline 9 & Inner Gullmarn & 34 & $58^{\circ} 25.333$ & $11^{\circ} 39.327$ & Yes & Yes & Yes & \\
\hline 10 & Alsbäck & 115 & $58^{\circ} 19.670$ & $11^{\circ} 33.102$ & Yes & Yes & & \\
\hline 11 & Koljöfjord & 42 & $58^{\circ} 13.830$ & $11^{\circ} 34.800$ & & & & Yes \\
\hline 12 & Byfjord & 42 & $58^{\circ} 20.309$ & $11^{\circ} 53.677$ & Yes & Yes & Yes & Yes \\
\hline 13 & Havstensfjord & 20 & $58^{\circ} 12.501$ & $11^{\circ} 51.506$ & Yes & Yes & Yes & Yes \\
\hline 14 & $\mathrm{~K} 2$ & 30 & $58^{\circ} 09.721$ & $11^{\circ} 51.315$ & Yes & Yes & & \\
\hline 15 & $\mathrm{G} 2$ & 25 & $58^{\circ} 06.139$ & $11^{\circ} 48.117$ & Yes & Yes & Yes & \\
\hline 16 & Stigfjord & 24 & $57^{\circ} 04.000$ & $11^{\circ} 33.750$ & & & & Yes \\
\hline 17 & A1 & 30 & $57^{\circ} 59.084$ & $11^{\circ} 45.334$ & Yes & Yes & & \\
\hline 18 & Åstol & 63 & $57^{\circ} 55.180$ & $11^{\circ} 35.600$ & & & & Yes \\
\hline 19 & Instö Ränna & 13 & $57^{\circ} 53.287$ & $11^{\circ} 39.490$ & Yes & & Yes & \\
\hline 20 & Danafjord & 38 & $57^{\circ} 40.075$ & $11^{\circ} 41.277$ & Yes & Yes & Yes & Yes \\
\hline 21 & Skalkorgarna & 9 & $57^{\circ} 40.909$ & $11^{\circ} 46.202$ & Yes & Yes & Yes & \\
\hline 22 & Älvsborgsbron & 15 & $57^{\circ} 41.955$ & $11^{\circ} 55.045$ & Yes & Yes & Yes & \\
\hline 23 & Valö & 22 & $57^{\circ} 32.826$ & $11^{\circ} 48.558$ & Yes & Yes & Yes & \\
\hline
\end{tabular}


Pelagic Monitoring Group at Kristineberg Marine Research Station and provided for Riksgränsen (Stn 1), Kosterfjord (Stn 3), Koljöfjord (Stn 11), Byfjord (Stn 12), Havstensfjord (Stn 13), Stigfjord (Stn 16), Åstol (Stn 18), and Danafjord (Stn 20) for the years 1993 to 1998 by the BVVF (2002, available at http://www.bvvf.com). Quan- titative species data (cells ${ }^{-1}$ ) from 0 to 5,5 to 10,10 to 15 , and 15 to $20 \mathrm{~m}$ depth were supplied. Monthly totals in species abundance were averaged from 0 to $20 \mathrm{~m}$ for the $6 \mathrm{yr}$, and relative abundance of the major species, and cyst-forming species, were calculated to give a general picture of the species composition at each site.

Table 2. Environmental variables used in partial least squares (PLS) and canonical correspondence (CCA) analyses. Variables in the upper part of the table are measured in sediment, variables in the lower part in the water column. All chemical analyses of the sediments are expressed per unit dry weight $(\mathrm{dw})$; winter values represent average from January to April, summer values from May to August; surface temperature and salinity values from Stns 19, 21 and 22 are integrated from 0 to $2 \mathrm{~m}$, all other surface values are integrated from 0 to $5 \mathrm{~m}$; values of deep water temperature, salinity and $\mathrm{O}_{2}$ concentration are from just above the sediment surface; nutrient and chl a concentration values represent 0 to $2 \mathrm{~m}$ at Stns 19,21, and 22, at all other stations the values represent 0 to $10 \mathrm{~m}$;

buoyancy frequency is calculated between 5 and $20 \mathrm{~m}$ depths, except at Stn 3 (5 and $30 \mathrm{~m}$ ) and Stns 19, 21 and 22 (2 and $10 \mathrm{~m})$

\begin{tabular}{|c|c|c|c|c|}
\hline Variable & Unit & Maximum & Minimum & Average \\
\hline Depth of sediment sampling & $\mathrm{m}$ & 115 & 9 & 35 \\
\hline Silt content $(<63 \mu \mathrm{m})$ & $\%$ & 99.0 & 36.2 & 85.6 \\
\hline $\mathrm{H}_{2} \mathrm{O}$ content & $\%$ & 90.9 & 46.9 & 69.1 \\
\hline Total organic carbon (TOC) & $\mathrm{mg} \mathrm{g}^{-1} \mathrm{dw}^{1}$ & 3.7 & 0.9 & 2.5 \\
\hline Polychlorinated biphenyls (PCB) & $\mu \mathrm{kg}^{-1} \mathrm{dw}$ & 69.3 & 2.0 & 14.0 \\
\hline Total hydrocarbons (THC) & $\mathrm{mg} \mathrm{kg} \mathrm{kg}^{-1} \mathrm{dw}$ & 222.5 & 0.6 & 50.6 \\
\hline Polycyclic aromatic hydrocarbons (PAH) & $\mu g g^{-1} d w$ & 2629.1 & 471.4 & 1136.8 \\
\hline Naftalen & $\mu g \mathrm{~kg}^{-1} \mathrm{dw}$ & 43.0 & 5.3 & 19.5 \\
\hline Extractable organically bound chlorine (EOCl) & $\mathrm{mg} \mathrm{kg}^{-1} \mathrm{dw}$ & 12.9 & 2.1 & 5.1 \\
\hline Extractable persistent organically bound chlorine (EPOCl) & $\mathrm{mg} \mathrm{kg}^{-1} \mathrm{dw}$ & 9.6 & 0.5 & 2.9 \\
\hline Hexachlorobenzene (HCB) & $\mu g \mathrm{~kg}^{-1} \mathrm{dw}$ & 1.8 & 0.1 & 0.4 \\
\hline 4-n-pentyl-4'-cyanobiphenyl (5CB) & $\mu g \mathrm{~kg}^{-1} \mathrm{dw}$ & 0.6 & 0.1 & 0.2 \\
\hline Total nitrogen in sediment & $\mathrm{mg} \mathrm{g}^{-1} \mathrm{dw}$ & 5.2 & 1.5 & 3.4 \\
\hline Total carbon in sediment & $\mathrm{mg} \mathrm{g}^{-1} \mathrm{dw}$ & 47.1 & 13.9 & 33.9 \\
\hline Inorganic carbon & $\mathrm{mg} \mathrm{g}^{-1} \mathrm{dw}$ & 17.9 & 4.4 & 9.1 \\
\hline Cadmium & $\mathrm{mg} \mathrm{kg}^{-1} \mathrm{dw}$ & 0.6 & 0.0 & 0.2 \\
\hline Copper & $\mathrm{mg} \mathrm{kg}^{-1} \mathrm{dw}$ & 55.6 & 6.6 & 24.7 \\
\hline Mercury (Hg) & $\mathrm{mg} \mathrm{kg}{ }^{-1} \mathrm{dw}$ & 0.75 & 0.1 & 0.2 \\
\hline Nickel (Ni) & $\mathrm{mg} \mathrm{kg} \mathrm{kw}^{-1} \mathrm{dw}$ & 24.7 & 7.5 & 19.5 \\
\hline Lead $(\mathrm{Pb})$ & $\mathrm{mg} \mathrm{kg}^{-1} \mathrm{dw}$ & 41.8 & 17.5 & 32.0 \\
\hline Vanadium (V) & $\mathrm{mg} \mathrm{kg}^{-1} \mathrm{dw}$ & 92.3 & 27.3 & 63.5 \\
\hline Zinc (Zn) & $\mathrm{mg} \mathrm{kg}^{-1} \mathrm{dw}$ & 203.0 & 49.8 & 128.0 \\
\hline Winter surface water temperature ( 0 to $5 \mathrm{~m}$ ) & ${ }^{\circ} \mathrm{C}$ & 4.4 & 2.7 & 3.7 \\
\hline Winter deep water temperature & ${ }^{\circ} \mathrm{C}$ & 6.4 & 3.2 & 4.6 \\
\hline Summer surface water temperature ( 0 to $5 \mathrm{~m}$ ) & ${ }^{\circ} \mathrm{C}$ & 15.7 & 14.0 & 15.0 \\
\hline Summer deep water temperature & ${ }^{\circ} \mathrm{C}$ & 13.1 & 5.9 & 8.8 \\
\hline Winter surface salinity (0 to $5 \mathrm{~m}$ ) & PSU & 27.7 & 3.2 & 21.3 \\
\hline Winter deep salinity & PSU & 34.6 & 25.8 & 29.7 \\
\hline Summer surface salinity ( 0 to $5 \mathrm{~m}$ ) & PSU & 22.8 & 5.3 & 18.9 \\
\hline Summer deep salinity & PSU & 34.8 & 20.4 & 28.7 \\
\hline Winter $\mathrm{PO}_{4}{ }^{3-}-\mathrm{P}(0$ to $10 \mathrm{~m})$ & $\mu \mathrm{mol} 1^{-1}$ & 0.47 & 0.14 & 0.40 \\
\hline Summer $\mathrm{PO}_{4}{ }^{3-}-\mathrm{P}(0$ to $10 \mathrm{~m})$ & $\mu \mathrm{mol} 1^{-1}$ & 0.20 & 0.08 & 0.10 \\
\hline Winter total phosphorus (0 to $10 \mathrm{~m}$ ) & $\mu \mathrm{mol} 1^{-1}$ & 0.84 & 0.52 & 0.71 \\
\hline Summer total phosphorus ( 0 to $10 \mathrm{~m}$ ) & $\mu \mathrm{mol} 1^{-1}$ & 0.57 & 0.37 & 0.45 \\
\hline Winter $\mathrm{NO}_{3}^{-}-\mathrm{N}(0$ to $10 \mathrm{~m})$ & $\mu \mathrm{mol} \mathrm{l} 1^{-1}$ & 35.89 & 6.39 & 12.66 \\
\hline Summer $\mathrm{NO}_{3}^{-}-\mathrm{N}$ (0 to $\left.10 \mathrm{~m}\right)$ & $\mu \mathrm{mol} \mathrm{l} \mathrm{l}^{-1}$ & 27.75 & 0.10 & 3.61 \\
\hline Winter total nitrogen $(0$ to $10 \mathrm{~m})$ & $\mu \mathrm{mol} 1^{-1}$ & 66.28 & 19.72 & 29.24 \\
\hline Summer total nitrogen (0 to $10 \mathrm{~m}$ ) & $\mu \mathrm{mol} 1^{-1}$ & 54.53 & 18.88 & 24.12 \\
\hline Winter $\mathrm{SiO}_{3}(0$ to $10 \mathrm{~m})$ & $\mu \mathrm{mol} \mathrm{l}^{-1}$ & 36.23 & 7.12 & 15.45 \\
\hline Summer $\mathrm{SiO}_{3}(0$ to $10 \mathrm{~m})$ & $\mu \mathrm{mol} \mathrm{l} \mathrm{l}^{-1}$ & 12.21 & 0.86 & 2.73 \\
\hline Winter chl a $(0$ to $10 \mathrm{~m})$ & $\mu \mathrm{g} \mathrm{l}^{-1}$ & 2.93 & 1.52 & 2.14 \\
\hline Summer chl $a$ (0 to $10 \mathrm{~m})$ & $\mu \mathrm{gl}^{-1}$ & 5.30 & 2.38 & 3.98 \\
\hline Winter $\mathrm{O}_{2}$ deep water & $\mathrm{ml} \mathrm{l} \mathrm{l}^{-1}$ & 7.79 & 0.00 & 6.14 \\
\hline Summer $\mathrm{O}_{2}$ deep water & $\mathrm{ml} \mathrm{l}^{-1}$ & 6.51 & 0.00 & 4.61 \\
\hline Winter buoyancy frequency & $\left(\right.$ cycles s$\left.^{-1}\right)$ & 0.15 & 0.03 & 0.06 \\
\hline Summer buoyancy frequency & $\left(\right.$ cycles s $\left.^{-1}\right)$ & 0.12 & 0.05 & 0.07 \\
\hline
\end{tabular}


Environmental variables. Physical and chemical data from the sediment (Table 2) for all stations, except one (Stn 19, Instö Ränna, Table 1), were obtained from the BVVF (Cato 1997). The sediments for chemical and physical analyses were collected from the same cores as the sediments used for dinoflagellate cyst analyses. All chemical parameters are expressed per unit sediment dw.

Hydrographic data (Table 2) were acquired once a month for 11 of the stations (Table 1) during the period January to August 1995, from the BVVF (2002, available at http://www.bvvf.com). This period has been divided into winter, using average values from January to April, and summer, using average values from May to August. Surface water temperature and salinity are integrated from 0 to $5 \mathrm{~m}$ except at the stations Instö Ränna, Skalkorgarna, and Älvsborgsbron (Stns 19, 21 and 22) where the values are integrated from 0 to $2 \mathrm{~m}$. This is due to the shallow depths of these stations. Nutrient concentrations and chl $a$ are integrated from 0 to $10 \mathrm{~m}$ except at Stns 19, 21 and 22, where the values are integrated from 0 to $2 \mathrm{~m}$. Deep-water temperature, salinity, and oxygen concentrations are from just above the sediment surface. As a measure of water column stability, the Brunt-Väisälä (or buoyancy) frequency, $N$, was calculated by:

$$
N=\sqrt{\frac{-g}{z_{2}-z_{1}} \cdot \frac{\rho_{2-} \rho_{1}}{\rho_{1}}}
$$

where $g$ is gravitational acceleration $\left(\mathrm{m} \mathrm{s}^{-2}\right), z$ is depth $(\mathrm{m})$, and $\rho$ is density $\left(\mathrm{kg} \mathrm{m}^{-3}\right)$. Depths used in the calculation were 5 and $20 \mathrm{~m}$ for all stations except Kosterfjord, Instö Ränna, Skalkorgarna, and Älvsborgsbron (Stns 3, 19, 21 and 22). For Kosterfjord we used 5 and $30 \mathrm{~m}$ depths, since the pycnocline at this site was deeper. Depths selected for the $N$ calculation at Instö Ränna, Skalkorgarna, and Älvsborgsbron were 2 and $10 \mathrm{~m}$ since these sites were shallow.

Data analyses. The relationship between total number of dinoflagellate cysts and environmental variables was investigated with projection to latent structures by means of partial least squares analysis (PLS) (Wold et al. 1984), using the software SIMCA-P 8.0 (UMETRICS). PLS is a regression based on latent variables, and is used for finding the linear or polynomial relationship between a set of predictor variables $(x)$ and a set of response variables or a single response variable $(y)$. PLS has some advantages over multiple linear regression. PLS allows the number of predictor variables to be greater than that of the objects, can use multitudes of correlated $x$-variables (multivariate collinear data), and can tolerate certain amounts of missing data (Eriksson et al. 1999). The total number of cysts per gram sediment dw was used as the response variable $(y)$ in the model, PLS-total abundance. Two additional models were run using the response variables, total number of autotrophic species (PLS-autotroph abundance) and total number of heterotrophic species (PLS-heterotroph abundance) (Table 3). In all 3 models, an initial screening was performed using all 46 environmental variables listed in Table 2 as predictor variables. After the first PLS run, only predictor variables with a variable influence on the projection parameter (VIP) $>1$ were included in a second PLS, i.e. the models presented in Table 3. Only the stations where data on dinoflagellate cyst abundance, physical and chemical sediment characteristics, and hydrography were available were used in the 3 PLS models, i.e. 10 observations in all. All variables were ${ }^{10} \log (x+$ 0.1 transformed before analysis, and thereafter centred and scaled to unit variance.

Ordination was used to examine the relationships between species composition of the surface sediments, collection sites, and causative factors. Canonical correspondence analysis (CCA) (CANOCO Version 3.1, ter Braak 1987-1992) was selected as the unimodal response model since the gradient was more than $2 \mathrm{SD}$ (ter Braak \& Prentice 1988). The CCA included 46 environmental variables (Table 2) and 13 dinoflagellate taxa having over $2 \%$ relative abundance in at least 1 of the 10 sites for which complete environmental data was available (Table 4). The taxonomy of the genus Gonyaulax spp. has recently been reconstructed (e.g. Lewis et al. 2001, Ellegaard et al. 2002, 2003), clarifying earlier confusion. Accordingly, paleontological taxa for cyst types belonging to this genus have been included in Table 4. Species percentages were arcsinetransformed and environmental data were ${ }^{10} \log (x+$

Table 3. Models fitting partial least squares (PLS) analysis on environmental variables $(x)$ with a variable influence on the projection parameter (VIP) $>1$ in initial screening and total abundance, abundance of autotrophic and abundance of heterotrophic dinoflagellate cysts per gram sediment (dry weight; dw) as response variable $(y)$. For further details see 'Materials and methods'. $k=$ number of components; $\mathrm{R}^{2} x(\mathrm{cum})=$ fraction of sum of squares of all the $x$-variables explained by the components; $R^{2} y(\mathrm{cum})=$ fraction of sum of squares of $y$ variable explained; $\mathrm{Q}^{2}(\mathrm{cum})=$ fraction of the total variation of the $y$-variable that can be predicted by the components

\begin{tabular}{|c|c|c|c|c|c|}
\hline Model & $k$ & Eigenvalue & $\begin{array}{c}\mathrm{R}^{2} \boldsymbol{X} \\
\text { (cum) }\end{array}$ & $\begin{array}{c}\mathrm{R}^{2} y \\
\text { (cum) }\end{array}$ & $\begin{array}{c}\mathrm{Q}^{2} \\
(\mathrm{cum})\end{array}$ \\
\hline PLS-total cyst abundance & 1 & 4.002 & 0.400 & 0.758 & 0.677 \\
\hline PLS-autotroph abundance & 1 & 5.060 & 0.506 & 0.787 & 0.737 \\
\hline PLS-heterotroph abundance & 2 & $5.65(1.4781)^{\mathrm{a}}$ & 0.792 & 0.889 & 0.666 \\
\hline
\end{tabular}


Table 4. Cysts of different taxa recorded from sediment samples and included in data analysis. Occurrence column is number of occurrences in the investigated stations (max. 19), maximum column is maximum at any given station, and mean column is mean from all 19 stations. CCA: canonical correspondence analysis, PLS: partial least squares analysis

\begin{tabular}{|c|c|c|c|c|c|}
\hline CCA code & $\begin{array}{l}\text { Taxa included in } \\
\text { data analysis }\end{array}$ & Species constituting PLS/CCA taxa & Occurrence & $\begin{array}{l}\text { Maximum } \\
(\%)\end{array}$ & $\begin{array}{c}\text { Mean } \\
(\%)\end{array}$ \\
\hline \multirow[t]{3}{*}{ Alex } & \multirow[t]{3}{*}{ Alexandrium spp. } & Alexandrium minutum Halim & 13 & 3.3 & 0.9 \\
\hline & & Alexandrium tamarense (Lebour) Balech & 11 & 1.1 & 0.2 \\
\hline & & Alexandrium spp. & 19 & 5.1 & 1.5 \\
\hline \multirow[t]{3}{*}{ G.dig } & \multirow[t]{3}{*}{ Gonyaulax digitale } & Gonyaulax digitale (Pouchet) Kofoid & & & \\
\hline & & Spiniferites bentorii (Rossignol) Wall et Dale & 11 & 4.5 & 1.2 \\
\hline & & Bitectatodinium tepikiense Wilson & 8 & 1.1 & 0.1 \\
\hline \multirow[t]{3}{*}{ G.scr } & \multirow[t]{3}{*}{ Gonyaulax scrippsae } & Gonyaulax scrippsae Kofoid & & & \\
\hline & & Gonyaulax baltica Ellegaard, Lewis et Harding & & & \\
\hline & & $\begin{array}{l}\text { Spiniferites bulloideus (Deflandre et Cookson) } \\
\text { Sarjeant }\end{array}$ & 15 & 5.2 & 2.1 \\
\hline \multirow[t]{6}{*}{ G.spi } & \multirow{6}{*}{$\begin{array}{l}\text { Gonyaulax spinifera } \\
\text { complex }\end{array}$} & Spiniferites elongatus Reid & 7 & 1.7 & 0.2 \\
\hline & & Spiniferites membranaceus (Rossignol) Sarjeant & 5 & 0.4 & 0.05 \\
\hline & & Spiniferites mirabilis (Rossignol) Sarjeant & 15 & 1 & 0.3 \\
\hline & & Spiniferites pachydermus (Rossignol) Reid & 1 & 0.2 & 0.01 \\
\hline & & Spiniferites ramosus (Ehrenberg) Mantell & 3 & 0.7 & 0.1 \\
\hline & & Spiniferites spp. & 11 & 7.3 & 2.5 \\
\hline G.ver & Gonyaulax verior & Gonyaulax verior Sournia & 11 & 4.8 & 0.8 \\
\hline L.pol & Lingulodinium polyedrum & Lingulodinium polyedrum (Stein) Dodge & 19 & 61.8 & 29.2 \\
\hline P.ret & Protoceratium reticulatum & $\begin{array}{l}\text { Protoceratium reticulatum (Claparède et Lachmann) } \\
\text { Bütschli }\end{array}$ & 19 & 34.8 & 17 \\
\hline P.dal & Pentapharsodinium dalei & Pentapharsodinium dalei Indelicato et Loeblich III & 19 & 20.8 & 7.1 \\
\hline \multirow[t]{2}{*}{ Scri } & \multirow[t]{2}{*}{ Scrippsiella spp. } & Scrippsiella trochoidea (Stein) Balech & 19 & 28.8 & 10.4 \\
\hline & & Scrippsiella lachrymosa Lewis & 7 & 2.5 & 0.3 \\
\hline G.nol & Gymnodinium nolleri & Gymnodinium nolleri Ellegaard et Moestrup & 17 & 11.5 & 2.4 \\
\hline P.sch & Polykrikos schwartzii & Polykrikos schwartzii Bütschli & 18 & 3.9 & 1.3 \\
\hline \multirow[t]{7}{*}{ Dipl } & \multirow[t]{7}{*}{ Diplopsalis group } & Diplopelta parva (Abé) Matsouka & 9 & 0.4 & 0.1 \\
\hline & & Diplopelta symmetrica Pavillard & 11 & 1 & 0.2 \\
\hline & & Diplopsalis lebourae (Nie) Balech & 1 & 0.4 & 0.02 \\
\hline & & Diplopsalis lenticula Bergh & 6 & 0.8 & 0.2 \\
\hline & & Diplopsalopsis latipeltata Balech et Borgese & 8 & 4.8 & 0.6 \\
\hline & & Diplopsalopsis orbicularis (Paulsen) Lebour & 7 & 1 & 0.2 \\
\hline & & $\begin{array}{l}\text { Zygabikodinium lentikulatum (Paulsen) } \\
\text { Loeblich et Loeblich }\end{array}$ & 1 & 1 & 0.05 \\
\hline \multirow[t]{15}{*}{ Prot } & \multirow[t]{15}{*}{ Protoperidinium spp. } & $\begin{array}{l}\text { Protoperidinium americanum (Gran et Braarud) } \\
\text { Balech }\end{array}$ & 14 & 6.6 & 1 \\
\hline & & Protoperidinium avellana (Meunier) Balech & 11 & 2.6 & 0.7 \\
\hline & & Protoperidinium claudicans (Paulsen) Balech & 4 & 2.9 & 0.2 \\
\hline & & Protoperidinium conicoides (Paulsen) Balech & 13 & 5.1 & 0.7 \\
\hline & & Protoperidinium conicum (Gran) Balech & 14 & 3.6 & 0.8 \\
\hline & & Protoperidinium divaricatum (Meunier) Balech & 2 & 0.4 & 0.02 \\
\hline & & Protoperidinium excentricum (Paulsen) Balech & 4 & 0.4 & 0.07 \\
\hline & & Protoperidinium leonis (Pavillard) Balech & 3 & 0.4 & 0.04 \\
\hline & & Protoperidinium minutum (Kofoid) Loeblich III & 1 & 0.3 & 0.02 \\
\hline & & Protoperidinium nudum (Meunier) Balech & 5 & 0.9 & 0.1 \\
\hline & & $\begin{array}{l}\text { Protoperidinium oblongum (Aurivillius) } \\
\text { Parke et Dodge }\end{array}$ & 18 & 1.8 & 0.7 \\
\hline & & Protoperidinium pentagonum (Gran) Balech & 1 & 0.3 & 0.02 \\
\hline & & Protoperidinium punctulatum (Paulsen) Balech & 4 & 0.4 & 0.07 \\
\hline & & Protoperidinium stellatum Wall & 1 & 0.4 & 0.02 \\
\hline & & Protoperidinium subinerme (Paulsen) Loeblich III & 2 & 0.6 & 0.05 \\
\hline
\end{tabular}

0.1)-transformed before analysis. Neither environmental nor species data were weighted. Since many of the environmental variables were highly correlated, an initial CCA screening, with each variable run separately, was performed to check the significance of the variable to the first axis and the percentage of variance 
explained. The initial screening identified 8 variables $(\mathrm{p}<0.05)$ as having the most influence. The final CCA included all 19 stations where dinoflagellate cyst analyses had been performed. Ten stations, where both sediment and hydrography data were available, were treated as active cases, and the remaining 9 stations were treated as passive cases.

\section{RESULTS}

\section{General description of distribution and frequencies of dinoflagellate cysts}

A detailed description of species distribution and frequencies of dinoflagellate cysts from these sediment samples has previously been reported (Persson et al. 2000). Generally, higher concentrations of dinoflagellate cysts were found in the inner fjord areas (Stns 7-9 and 12-15) compared to coastal sites (Fig. 2). Maximum density (101 000 cysts $\mathrm{g}^{-1} \mathrm{dw}$ ) was recorded from Havstensfjord (Stn 13) and minimum density (5000 cysts g ${ }^{-1} \mathrm{dw}$ ) was recorded from Valö (Stn 23).

Cysts of the major dinoflagellate taxa (Table 4) showed different distributions along the coast (Fig. 3). In the following section, all references to abundance shall denote relative abundance rather than absolute abundance, except where specifically noted. Alexandrium spp. (Alex) were present in low abundance at the northern stations, showed a maximum at Alsbäck (Stn 10), and were more abundant at the southern stations (Stns 19-22). Gonyaulax digitale (G.dig; Table 4) was not recorded from the northern stations (Stns 2-7). It was present in the Gullmarfjord system (Stns 8-10, maximum $4.3 \%$ ), absent in the fjords around Tjörn and Orust, and reappeared in the southern stations (Stns 17-23, maximum 4.5\%). G. scrippsae (G.scri; Table 4) was recorded at almost all stations and displayed highest abundance in Gullmarfjord (Stns 8-9) and in the south (Stns 21-22). The G. spinifera complex (G.spi; Table 4) had its highest proportions at the northern sites (Stns 2-7). At Strömstad (Stn 2), the G. spinifera complex constituted $10 \%$ of the cyst assemblage. Cysts of this complex showed a somewhat lower peak at S 112 (Stn 5). At the southern stations, the abundance was comparatively low. G. verior (G.ver) was a minor contribution to the cyst assemblage at most stations; only Älvsborgsbron (Stn 22) had a higher proportion of G. verior (4.8\%). Lingulodinium polyedrum (L.pol) was the most abundant cyst type encountered. The abundance of this species was comparatively less at the northern stations (maximum $21.5 \%$ ), reaching highest abundances in the inner fjords (Stns 8-9 and 13-17). Protoceratium reticulatum (P.ret) was the second most common species. This cyst type was most frequent in the northern and southern stations (maximum abundance $34.8 \%$ at Skalkorgarna, Stn 21) but was less abundant (minimum $0.2 \%$ ) in the fjords around Tjörn and Orust (Stns 12-17). Pentapharsodinium dalei (P.dal) was present at all stations in proportions ranging from $3.4 \%$ at Färlevfjord (Stn 8 ) to $20.8 \%$ at G2 (Stn 15). Scrippsiella spp. (Scri) was present at all sites, and most abundant around Gullmarfjord, displaying a maximum at Alsbäck (Stn 10) of $29.4 \%$. Gymnodinium nolleri (G.nol) was present in low abundances at the northern stations and Gullmarfjord (Stns 2-10). This species was rarely encountered in the fjords inside Tjörn and Orust. G. nolleri was absent at the most southern station (Valö, Stn 23), but constituted a minor part of the cyst assemblage at the other southern stations, reaching a maximum of $11.5 \%$ at Danafjord (Stn 20). Polykrikos schwartzii (P.sch) was most commonly encountered at the northern stations, the Gullmarfjord stations and the southern coastal stations, reaching a maximum at Fjällbacka (Stn 4) of 3.9\%. Very few specimens were encountered in the fjords around Tjörn and Orust (Stns 12-17). Cysts of the

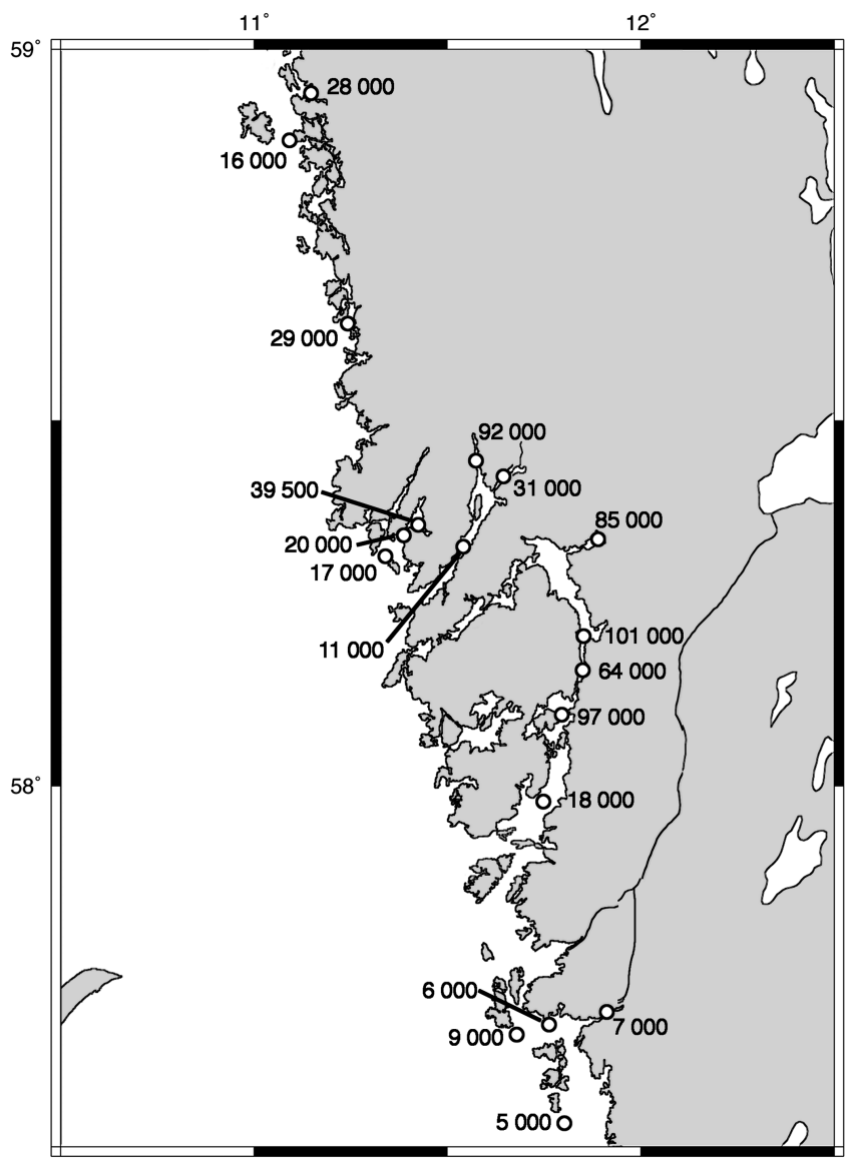

Fig. 2. Number of dinoflagellate cysts per gram sediment (dry weight) at the sampling stations 


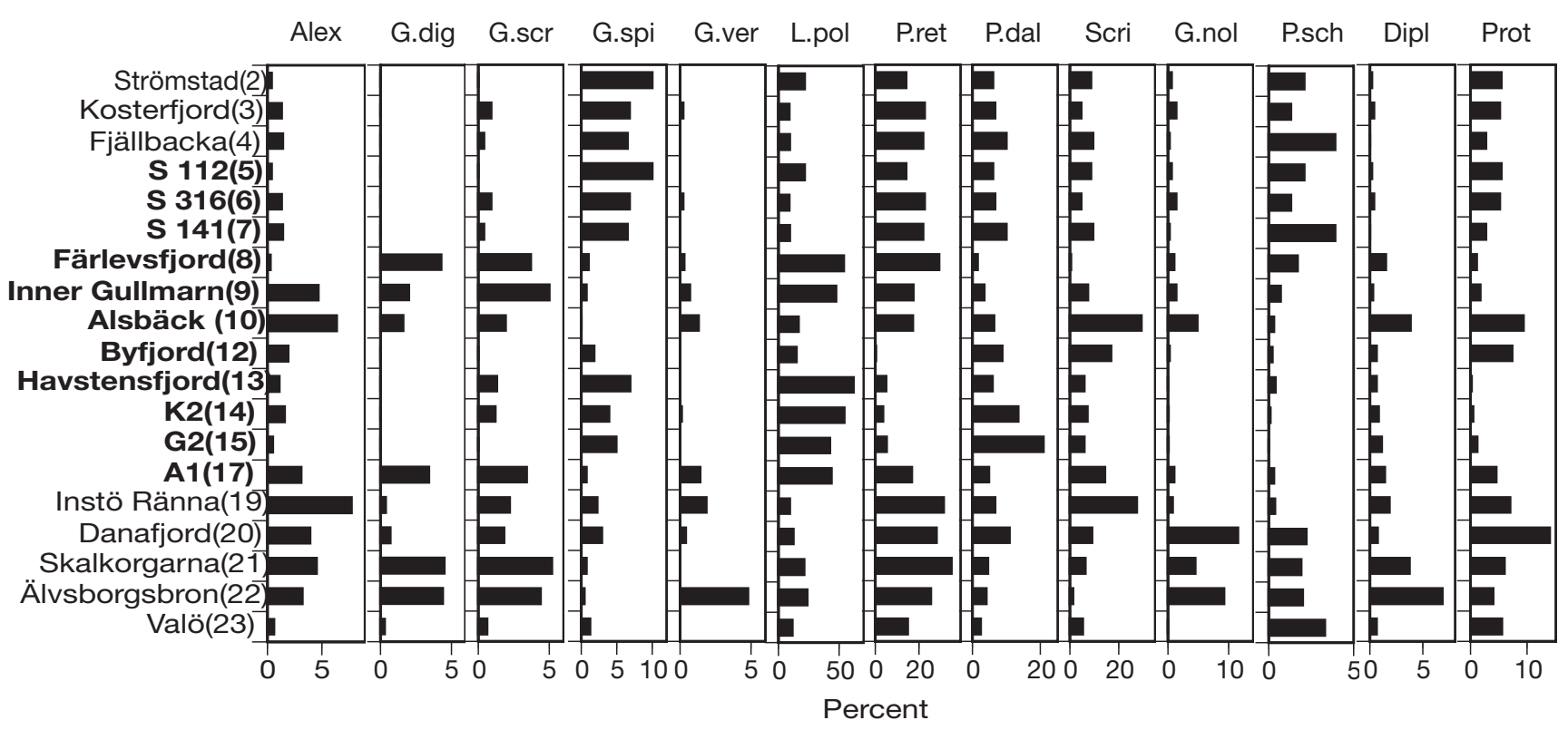

Fig. 3. Percentage of major dinoflagellate taxa from the total cyst assemblages present in sediment from the sampling stations. Fjord stations are indicated in bold text, station numbers are in parentheses after station name. For taxa abbreviations see Table 4

Diplopsalis group (Dipl) constituted a minor proportion $(<1-3 \%)$ at all stations except Fjällbacka (Stn 4) where it was absent. Only at Älvsborgsbron (Stn 22) was its abundance higher $(6.8 \%)$. Protoperidinium spp. (Prot) abundances were moderately high at the northern stations and in Gullmarfjord (Stns 2-12). The proportion decreased in the southern part of the Orust-Tjörn Fjord system (Stns 13-17), and was more common at the southern stations (maximum 14\% at Danafjord, Stn 20).

In Fig. 4A the cyst assemblages from 4 sites were compared to plankton records from the same locations. Only species constituting $\geq 5 \%$ of the plankton or sediment assemblage at any of the 4 sites were depicted. The 2 most common species in the sediment, Lingulodinium polyedrum and Protoceratium reticulatum, did not constitute $\geq 5 \%$ of the plankton assemblage at any of the sites. The most common taxa of the plankton community were either Gymnodinium spp. (primarily G. simplex and $G$. lohmanni) or Prorocentrum spp. (P. micans, P. minimum, $P$. balticum). The only taxa present in high abundance $(>5 \%)$ in both plankton and sediment were Scrippsiella spp. and Protoperidinium spp.

A comparison of the relative abundance of cystforming dinoflagellate species in plankton and their counterpart cysts in the sediment from the same site is displayed in Fig. 4B. The most frequent cyst-forming species $(>2 \%$ in any of the investigated sediment sites and $>0 \%$ at any plankton site) are depicted. Generally, Alexandrium spp. displayed a higher abundance in the plankton samples. The abundance of Gonyaulax digitale (see Table 4 for different cyst types) was low both in plankton and sediment. For specimens belonging to the G. spinifera complex, abundances (Table 4) were similar in plankton and sediment. However, there was a difference between sites. At Kosterfjord (Stn 3) the $G$. spinifera complex constituted $10.8 \%$ of the cyst assemblage, whereas no cells were recorded from the plankton. In Havstensfjord (Stn 13) the cysts of the same taxa made up $7.8 \%$ of the total assemblage, while $18.6 \%$ of the cyst-forming dinoflagellates in the plankton belonged to the G. spinifera complex. The relative abundances of Lingulodinium polyedrum were similar in plankton and sediment, except for Havstensfjord (Stn 13) where it was more plentiful in the sediment. Protoceratium reticulatum was more abundant in the sediment at the coastal sites (Kosterfjord and Danafjord), and had equal or higher abundance in the plankton at the fjord sites (Byfjord and Havstensfjord). The abundance of Scrippsiella spp. was always higher in the plankton compared to the sediment. Polykrikos schwartzii and members of the Diplopsalis group displayed equally low abundance in both plankton and sediment. The abundance of Protoperidinium spp. was similar in plankton and sediment, with the exception of Byfjord, where abundance of the taxa was low in the plankton $(1.3 \%)$ but higher in the sediment $(13.9 \%)$.

\section{Relationship between environmental factors and cyst abundance}

All 3 models from the PLS analyses were significant. The cross-validated variance statistic $\left(Q^{2}\right)$ is 
significant if larger than a critical value $\left(Q^{2}\right.$ limit $\left.=0.097\right)$, which corresponds to $\mathrm{p}<0.05$. The 1-component model, PLS-total cyst abundance (Table 3), explained $75.8 \%$ of the variation of cyst abundance. The model used total cyst abundance as the response variable, and, as predictor variables, only those variables displaying a VIP $>1$ in the initial screening (data not shown). The predicted fraction of the variation of cyst abundance was $67.7 \%$. The variables with the highest influence on the model (high VIPs) and their respective regression coefficients are listed in Table 5A. The principal environmental variable influencing the total cyst abundance was summer surface water temperature. The next most important were total nitrogen in sediment, winter surface water $\mathrm{PO}_{4}{ }^{3-}-\mathrm{P}$, and winter surface water chl a concentration.

Separate models were created using cyst abundance of autotrophic and heterotrophic taxa as response variables. Only the predictor variables displaying VIP scores $>1$ in the initial screening were used in the final models. The 1-component PLS model for autotrophic taxa (PLS-autotroph abundance, Table 3 ) explained $78.7 \%$ of the variation. The predicted fraction of the variation of cyst abundance from autotrophic taxa was $73.7 \%$. According to this model, the main variables affecting the abundance of cysts from autotrophic taxa were summer surface water temperature, sediment concentrations of vanadium, total nitrogen, total organic carbon and total carbon, and winter surface water chl a concentration (Table 5B). The most important variables in the model, PLS-autotroph abundance, were almost the same, and rank in nearly the same order as the most important variables in the model, PLS-total cyst abundance. This is because the total cyst assemblages consisted predominantly of autotrophic taxa. The maximum percentage, $98.7 \%$, of autotrophic taxa was recorded at Havstensfjord (Stn 13), and the minimum at Valö (Stn 23), $79.5 \%$. The average percentage of autotroph taxa was $90.8 \%(\mathrm{n}=19)$.

The 2-component PLS model for heterotrophic taxa (PLS-heterotroph abundance, Table 3) explained 88.9\% of the variation. The predicted fraction of the variation of cyst abundance from heterotrophic taxa was $66.6 \%$. Accord- ing to this model, the main variables affecting the abundance of cysts from heterotrophic taxa (Table 5C) were extractable organically bound chlorine, extractable persistent organically bound chlorine, and summer buoyancy frequency. Furthermore, sediment concentrations of nickel, total nitrogen and vanadium, and silt content, influenced the abundance of heterotrophic cysts.

CCA was used to relate the distribution of different dinoflagellate cysts to environmental variables. In the CCA using the 8 selected environmental variables, the eigenvalues for Axes 1 (0.244) and 2 (0.131) explained $68.3 \%$ of the cumulative variance in the species data (Table 6). Contributing to this variance, the rank of the variables are: (1) summer surface water temperature, (2) mercury in sediments, (3) summer surface water salinity, (4) winter surface water $\mathrm{PO}_{4}{ }^{3-}-\mathrm{P}$ concentra-

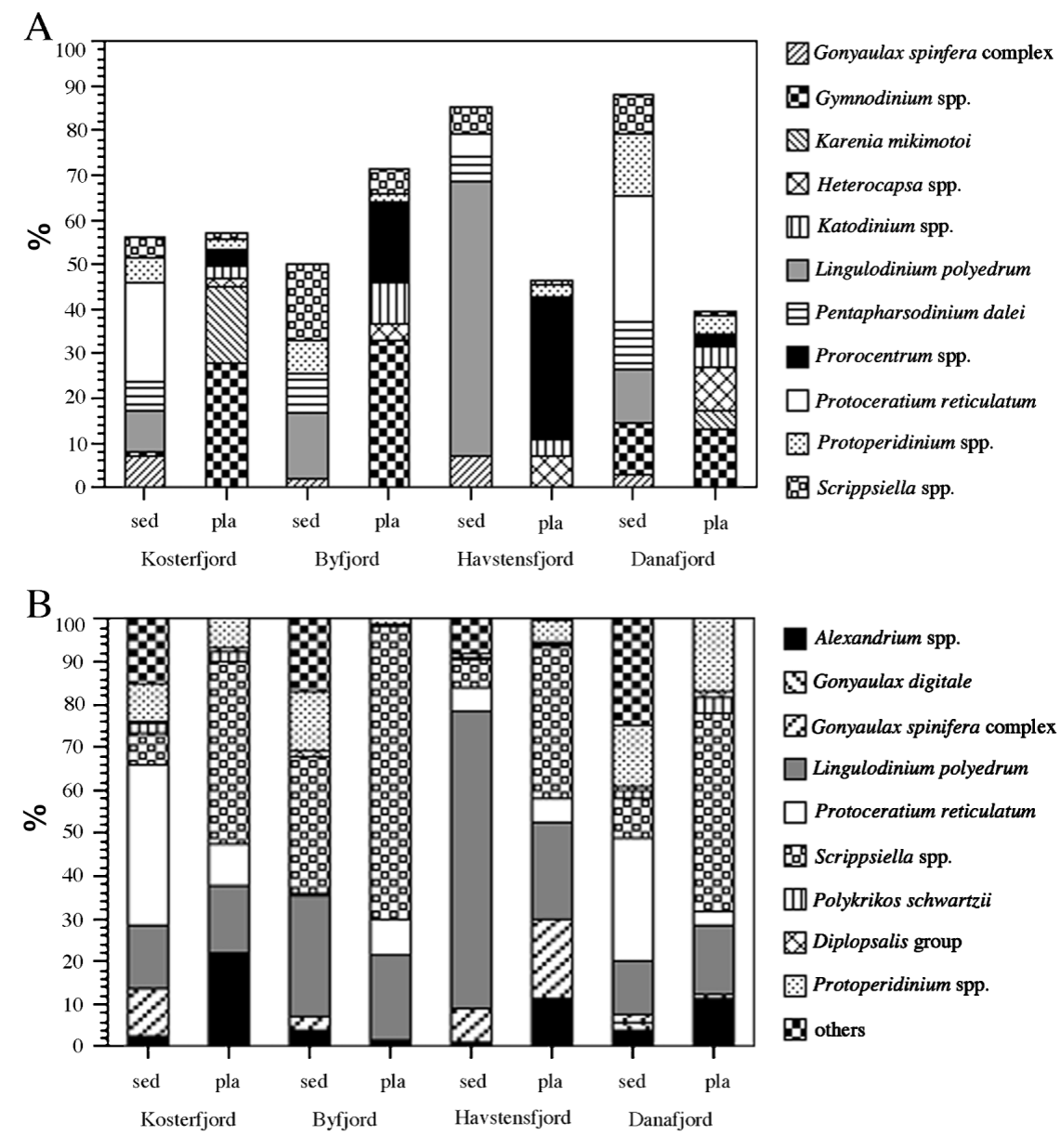

Fig. 4. Percentage of dinoflagellate taxa in plankton and sediment samples from 4 sampling stations along the Swedish west coast. Plankton data are averaged from monthly sampling during the period 1993-1998. Sed = sediment record, pla $=$ plankton record. (A) All dinoflagellate taxa (includes taxa representing $\geq 5 \%$ of the plankton population or the cyst assemblage). (B) Cyst-forming dinoflagellate taxa (includes taxa representing $\geq 2 \%$ of the sediment population and $>0 \%$ of the plankton population) 
Table 5. Variable importance (variable influence on projection, VIP) and regression coefficients for partial least squares analysis (PLS) analysis. (A) PLS-total cyst abundance. (B) PLS-autotroph abundance, (C) PLS-heterotroph abundance. Only variables with VIP $>1$ from initial screening of 46 environmental variables are used as predictor variables (see 'Materials and methods')

\begin{tabular}{|lcr|}
\hline Variable & VIP & Coefficient \\
\hline (A) & & \\
Summer surface water temperature & 1.6054 & 0.1125 \\
Total nitrogen in sediment & 1.2417 & 0.0870 \\
Winter PO ${ }^{3-}$-P & 1.2286 & 0.0861 \\
Winter chl $a$ & 1.2167 & -0.0852 \\
Total organic carbon & 1.1057 & 0.0775 \\
Total carbon in sediment & 1.1022 & 0.0772 \\
Vanadium & 1.0984 & 0.0769 \\
(B) & & \\
Summer surface water temperature & 1.3057 & 0.1105 \\
Vanadium & 1.2389 & 0.1049 \\
Total nitrogen in sediment & 1.1982 & 0.1014 \\
Total organic carbon & 1.1465 & 0.0971 \\
Total carbon in sediment & 1.1330 & 0.0959 \\
Winter chl a & 1.0249 & -0.0868 \\
(C) & & \\
Extractable organically & & \\
bound chlorine & 1.1324 & -0.2189 \\
Extractable persistent organically & 1.1769 & -0.2043 \\
$\quad$ bound chlorine & & \\
Summer buoyancy frequency & 1.1588 & -0.2070 \\
Nickel & 1.1315 & 0.1435 \\
Total nitrogen in sediment & 1.1233 & 0.1392 \\
Vanadium & 1.0462 & 0.1244 \\
Silt content & 1.0344 & 0.1044 \\
\hline & & \\
\hline
\end{tabular}

tion, (5) summer surface water total nitrogen concentration, (6) summer buoyancy frequency, (7) winter surface water chl a concentration, and (8) summer deep water temperature. Three of these variables were closely correlated. As a consequence, high (>20) variance inflation factor (VIF) values were noted for summer surface salinity (SS0), summer total nitrogen concentration (STN), and winter $\mathrm{PO}_{4}{ }^{3-}-\mathrm{P}$ concentration (WPO) (Table 7). The species-environment correlations for Axes 1 (1.000) and 2 (0.973) were high. Based on the interset correlations, summer surface temperature (ST0) and WPO were most strongly related to Axis 1; and mercury (Hg) and STN dominated Axis 2 (Table 6).

Positions of the sampled sites on a CCA biplot reflect their species composition and association to the environmental factors (Fig. 5). Further, the length of environmental arrows and
Table 6. Interset correlations between first 2 species axes and environmental variables in canonical correspondence analysis $(\mathrm{CCA})$. Summer = May-August, winter = January-April

\begin{tabular}{|lcc|}
\hline Variable & Axis 1 & Axis 2 \\
& $\lambda_{1}=0.244$ & $\lambda_{2}=0.131$ \\
\hline Mercury & -0.704 & -0.498 \\
Summer surface temperature & 0.865 & -0.089 \\
Summer surface salinity & 0.684 & 0.37 \\
Winter PO ${ }^{3-}$-P (0 to 10 m) & 0.739 & 0.097 \\
Summer total nitrogen (0 to 10 m) & -0.604 & -0.415 \\
Winter chl a & -0.573 & 0.331 \\
Summer deep temperature & -0.577 & -0.361 \\
Summer buoyancy frequency & -0.608 & -0.309 \\
\hline
\end{tabular}

their orientation indicates their relative importance and approximate correlations to the axes (Fig. 5B). Arrows point in the direction of increase of the environmental gradient, with the origin representing the average.

Axis 1 separates the stations based on ST0 and WPO (Fig. 5A). Thus, in the upper left corner are the wellmixed stations in the outer archipelago: Kosterfjord (Stn 3), Fjällbacka (Stn 4), Danafjord (Stn 20), and Valö (Stn 23). These stations have comparatively low summer surface temperatures. In contrast, the stations situated in the lower right corner are primarily within the fjord systems and have stratified water with high summer surface temperatures, these include A1 (Stn 17), S141 (Stn 7), Inner Gullmarn (Stn 9), G2 (Stn 15), K2 (Stn 14), and Havstensfjord (Stn 13). Axis 2 separates the stations based on mercury $(\mathrm{Hg})$ and STN. The stations in the lower left corner, such as Skalkorgarna (Stn 21), Älvsborgsbron (Stn 22), and Färlevsfjord (Stn 8), are situated at outflows of large rivers, and hence are exposed to high nitrogen inputs (STN). These sites are shallow, thus the deep-water temperatures (STD) are relatively high. This is in contrast to the deep fjord stations in the upper right corner, Byfjord

Table 7. Correlation among the 8 environmental variables selected for canonical correspondence analysis (CCA). Hg = mercury in sediment, $\mathrm{ST} 0=$ summer surface temperature, $\mathrm{SSO}=$ summer surface salinity, WPO = winter phosphate, $\mathrm{STN}$ = summer total nitrogen, $\mathrm{WCH}=$ winter $\mathrm{chl} a, \mathrm{STD}=$ summer deep temperature, $\mathrm{SBF}=$ summer buoyancy frequency

\begin{tabular}{|lrrrrrrrr|}
\hline & Hg & ST0 & SS0 & WPO & STN & WCH & STD & SBF \\
\hline Hg & 1 & & & & & & & \\
ST0 & -0.49 & 1 & & & & & & \\
SS0 & -0.85 & 0.67 & 1 & & & & & \\
WPO & -0.74 & 0.76 & 0.91 & 1 & & & & \\
STN & 0.92 & -0.39 & -0.88 & -0.78 & 1 & & & \\
WCH & 0.03 & -0.59 & -0.05 & -0.32 & -0.17 & 1 & & \\
STD & 0.72 & -0.59 & -0.78 & -0.81 & 0.75 & 0.25 & 1 & \\
SBF & 0.69 & -0.56 & -0.92 & -0.86 & 0.80 & -0.04 & 0.66 & 1 \\
\hline
\end{tabular}


(Stn 12) and S 112 (Stn 5), with low summer deep temperatures. Further, at Skalkorgarna (Stn 21) and Älvsborgsbron (Stn 22), the combination of freshwater flow from the large Göta River, together with the pronounced salt wedge, produces a strong halocline, which in turn is the primary contributor to the high summer buoyancy frequency (SBF). Skalkorgarna (Stn 21) and Älvsborgsbron (Stn 22) are also situated just outside Göteborg, the major industrial city of the Swedish west coast.

CCA Axes 1 and 2 explained $68.3 \%$ of the variance in the species-environment biplot (Fig. 5B). Axis 1 separates species based on summer surface temperature (ST0) and water stratification (SBF). Hence, most dinoflagellate taxa are present on the left side of the diagram. Many dinoflagellate taxa are located in the lower left corner where stratification (SBF) and nitrogen concentration (STN) are highest. The heterotrophic taxa, Protoperidinium spp. (Prot) and Polykrikos schwartzii (P.sch), occupy the upper left corner indicating greater abundance at stations with high winter chl a concentrations. Chlorophyll is a sign of considerable winter biomass, which is predominantly diatoms, a potential food source for heterotrophs. The association of these heterotrophs with high chlorophyll may be due to higher growth in food-rich areas. The smaller heterotrophic dinoflagellate taxon, Diplopsalis spp. (Dipl), is present in the lower left corner, indicating its generalist feeding behaviour and presence almost all year round. Lingulodinium polyedrum (L.pol) cysts have highest abundances in the sediments of the inner fjords, and thus this species lies at the lower right of the biplot (Fig. 5).

\section{DISCUSSION}

Cyst densities were greater in the inner fjord systems compared to the stations in the outer archipelago (Fig. 2). The highest concentrations (ca. $100000 \mathrm{~g}^{-1} \mathrm{dw}$ ) were found in Havstensfjord (Stn 13), G2 (Stn 15), and Färlevsfjord (Stn 8). These densities are comparable to other investigated areas in the temperate zone (Wall et al. 1977, Dale \& Fjellså 1994, Thorsen \& Dale 1997).

Summer surface water temperature was selected by both PLS and CCA as an important environmental factor regulating autotrophic dinoflagellate cyst abundance (Tables 5A,B \& 6). Summer surface temperatures were generally highest at the fjord stations (Fig. 5). Higher temperature has a direct positive effect on metabolic rate, and hence dinoflagellate growth in general. It also enhances the vertical stability of the water column, which most autotrophic dinoflagellate taxa tend to favour (Karentz \& Smayda 1984, Taylor \& Pollingher 1987, Kjœret et al. 2000). The fjord stations are generally stratified in terms of salinity and temper- ature, and thus a higher surface temperature can develop at these sites compared to coastal sites, where the water column is less stable (Lindahl et al. 1998, McQuoid \& Nordberg 2003). Our results show that these fjord stations had the highest cyst concentrations overall and were dominated by Lingulodinium polyedrum, which can reach densities greater than 62000 cysts g $^{-1} \mathrm{dw}$.

The second most important variable emerging in the analysis, PLS-total cyst abundance, was total nitrogen concentration in the sediment (Table 5A). Nitrogen concentration in the sediment reflects what has previously been present in the water column. The high rank-
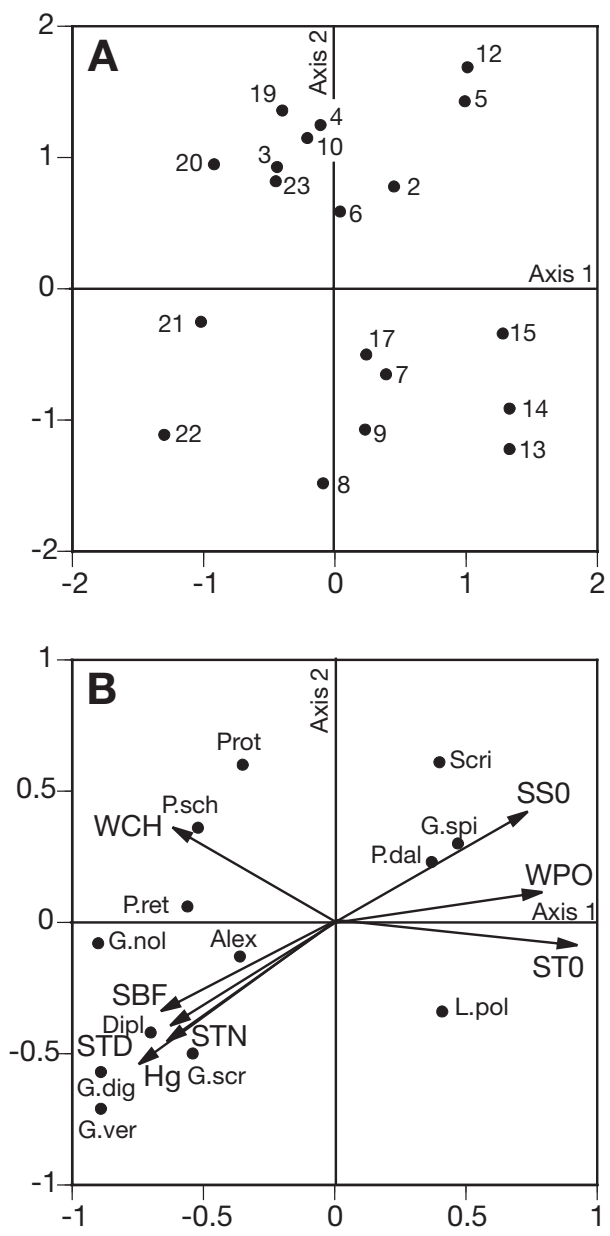

Fig. 5. Canonical correspondence analysis (CCA) biplot for relative abundance of dinoflagellate cysts in surface sediment, together with the associated benthic and pelagic environmental variables. (A) Sample scores of 19 study sites on the Swedish west coast. (B) Species scores of 13 dinoflagellate taxa. For environmental variable abbreviations see Table 7 . Site numbers are listed in Table 1, species codes are listed in Table 4. Eigenvalues for Axis $1\left(\lambda_{1}\right)=0.244$ and for Axis $2\left(\lambda_{2}\right)$ $=0.131$. Environmental vectors were omitted from (A) for clarity, but would be arranged as in (B) 
ing of nitrogen in the PLS analysis probably reflects the importance of this macronutrient for autotrophic dinoflagellate growth. Dinoflagellates are able to utilize organic sources of nitrogen (Taylor \& Pollingher 1987, and references therein), which could explain why total nitrogen rather than inorganic nitrogen emerged as an important variable. In the CCA, summer concentration of total nitrogen in the water column also emerged as an important variable. The sites displaying highest total nitrogen concentrations were Stns 21 and 22 (38.5 and $54.53 \mu \mathrm{mol} \mathrm{l^{-1 }}$, respectively) (Fig. 5). Göta River is the largest river in Sweden and it carries water from Lake Vänern. This river is the major contributor to the inorganic nitrogen budget in the estuary outside Göta River (Selmer \& Rydberg 1993), which is where Stns 21 and 22 are situated. Stn 8, Färlevsfjord (treated as a passive site in the CCA due to lack of hydrographic data), is located at the mouth of Örekil River and is also subjected to runoff containing high levels of nitrogen. Many dinoflagellate taxa are congregated at the high end of the summer total nitrogen gradient (Fig. 5B). One of these taxa, Alexandrium spp., is known to prefer estuarine environments influenced by runoff (Anderson 1998, and references therein), and this may explain its relatively high contribution to the cyst assemblage at the stations located in or by the mouth of Göta River (Stns 19-22) (Fig. 3).

The third ranked environmental variable for the analysis, PLS-total cyst abundance, is winter concentrations of $\mathrm{PO}_{4}{ }^{3-}$. Phosphorus is an essential macronutrient, and the high ranking in the PLS and CCA was therefore expected. By CCA, the concentrations of winter $\mathrm{PO}_{4}{ }^{3-}$ are highest in the fjord sites (Fig. 5). This is difficult to explain since it is known that most of the $\mathrm{PO}_{4}{ }^{3-}$ available in the water column on the Swedish west coast is generated through upwelling and not through river runoff (Selmer \& Rydberg 1993, McQuoid $\&$ Nordberg 2003). Upwelling is not expected in the inner fjord sites due to their strong stratification; however, a temporary local upwelling event between January and April 1995 could explain the position of phosphate in the CCA biplot (Fig. 5), and also explain the congruence of the actual cyst count (Fig. 2) with the results of the PLS analysis. Based on the upwelling potentials of the investigated sites, the expected direction of the arrow representing winter $\mathrm{PO}_{4}{ }^{3-}$ concentrations in the CCA biplot would be the upper left corner (Fig. 5). However, the most abundant species encountered in the sediment samples, Lingulodinium polyedrum and 2 other abundant taxa, Scrippsiella spp. and Pentapharsodinium dalei, are found on the high end of the winter $\mathrm{PO}_{4}{ }^{3-}$ gradient in the CCA biplot (Fig. 5B), which agrees with the outcome of the PLS analysis.

Winter chl $a$ is ranked 4 th in the PLS analysis (Table 5A). Chl a concentrations, reflecting algal bio- mass from January to April, are inversely related to total cyst count. An extensive spring diatom bloom will deplete surface waters of nutrients essential for autotrophic dinoflagellate growth. Thus, we would expect autotrophic dinoflagellates to be disadvantaged when winter diatom biomass is high. The winter chl a vector in the CCA biplot is directed towards the upper left corner. This part of the biplot contains stations from the outer archipelago characterized by well-mixed water columns (Fig. 5A). In the CCA species plot (Fig. 5B), mainly the heterotrophic taxa, Protoperidinium spp. and Polykrikos schwartzii, are favoured by these conditions.

Autotrophic taxa dominated the dinoflagellate cyst assemblages at all investigated sites (average 90.8\%). Hence, the environmental variables influencing the density of autotrophic dinoflagellate cysts were very much the same as the variables influencing the density of the total cyst community. Some differences are discernible in the ranking of environmental variables (Table 5A,B). Summer surface water temperature, discussed above, is the highest ranked environmental variable. The second ranked variable, vanadium, is positively related to autotrophic dinoflagellate abundance (Table 5B). Oil and gas are rich in vanadium, therefore combustion of fossil fuels contributes to anthropogenic emission of vanadium. Another anthropogenic source of vanadium is ferrovanadium, used as an alloy within the steel industry (Cato 1997). Vanadium is an essential micronutrient for algae and constitutes parts of several enzymes (van den Hoek et al. 1995). In marine macroalgae, the enzyme vanadiumbromoperoxidase is essential for production of bromoform that plays an important role in eliminating epiphytic microalgae (Ohsawa et al. 2001). In species of biofouling diatoms, an absolute requirement of the same enzyme for substratum attachment has been reported (Johnson et al. 1995). An elevated concentration of vanadium has also been demonstrated to have an inhibitory effect on the photosynthesis of phytoplankton (Nalewajko et al. 1995). We found a significant regression between the number of dinoflagellate cysts belonging to autotrophic taxa and the concentration of vanadium ( $p<0.05$, data not shown). The concentration of vanadium was highest in Havstensfjord (Stn 13) and the Gullmarfjord sites (Stns 8-9), where the densities of cysts belonging to autotrophic taxa were highest. It is difficult to say whether vanadium has had any positive effect on autotrophic dinoflagellate growth itself, or whether, conversely, it has had a negative effect on the vegetative cells, such as inhibition of photosynthesis, and thus promoted increased encystment in those areas. The high ranking of vanadium might also be due to covariance with some other variable important for dinoflagellate growth. 
Two other environmental variables that emerged as important in the model PLS-autotroph abundance were total organic carbon and total carbon in the sediment (Table 5B). With these, it is most likely the cysts themselves that make a substantial contribution to the content of organic and total carbon in the sediment.

In contrast to larger zooplankton, ciliates and heterotrophic dinoflagellates are closely coupled to the timing of maximal food abundance because of their more rapid reproduction rates (Archer et al. 1996, Kjœret et al. 2000). In temperate coastal water, many heterotrophic dinoflagellate species are most abundant during the later part of the spring diatom bloom (Taylor \& Pollingher 1987). It is therefore not surprising to find Protoperidinium spp. and Polykrikos schwartzii at the high end of the winter chl a vector (Fig. 5B). Moreover, the stations situated near the high end of the winter chl a vector are stations more susceptible to water column mixing or upwelling (Fig. 5A). Here, oceanographic conditions favour diatoms, the primary food source of heterotrophic dinoflagellates, and consequently produce cyst banks with higher proportions of heterotrophic dinoflagellate species. Increased proportions of heterotrophic dinoflagellate cysts in upwelling areas have been demonstrated in earlier studies (Wall et al. 1977, Dale \& Fjellså 1994).

In the PLS model for heterotrophic dinoflagellate cysts, the inverse of summer buoyancy frequency, i.e. a mixed water column, scored high (Table 5C). This suggests that water column mixing results in relatively more cysts being produced from heterotrophic species, probably via an increased diatom-rich food supply. The majority of Protoperidinium species appear to be diatom grazers, but some species can also utilize dinoflagellate prey (Jeong 1999, Olseng et al. 2002). Field observations of planktonic Protoperidinium spp. populations from Oslofjord in Norway have shown that availability of food, i.e. diatoms and medium-sized autotrophic dinoflagellates, is more important than physical variables, such as temperature, in regulating population growth (Kjœret et al. 2000). This further supports the different ranking of the environmental variables in the PLS analysis for autotrophic and heterotrophic dinoflagellate taxa (Table 5B,C). Species belonging to the Diplopsalis group are regarded as generalists in feeding behaviour compared to Protoperidinium species (Naustvoll 2000). Hence, the different position of Diplopsalis in the CCA species biplot probably reflects variations in food source (Fig. 5B).

The 2 environmental parameters, extractable organically bound chlorine (EOCl) and extractable persistent organically bound chlorine (EPOCl), ranked high among important variables for heterotrophic dinoflagellate cyst distribution. These variables were inversely related to the abundance of heterotrophic cysts. A vari- ety of anthropogenic activities can cause high concentrations of EOCl and EPOCl in sediments and/or biological organisms, including the pulp-mill industry, use of pesticides, incineration, and sewage treatment (Cato 1997, Swedish EPA [Environmental Protection Agency] 2002, available at http://www.environ.se). Chlorinated pesticides such as DDT, chlordane, heptachlor, and lindane are known to inhibit photosynthesis (Taylor \& Pollingher 1987, and references therein) and thereby affect heterotrophic dinoflagellates indirectly. The highest concentrations of $\mathrm{EOCl}$ and $\mathrm{EPOCl}$ for the stations included in the PLS were from Inner Gullmarn and Byfjord $\left(\mathrm{EOCl}=9.6\right.$ and $12.9 \mathrm{mg} \mathrm{kg}^{-1} \mathrm{dw}$, respectively, and $\mathrm{EPOCl}=3.2$ and $7.9 \mathrm{mg} \mathrm{kg}^{-1} \mathrm{dw}$, respectively). These concentrations are classified as Category IV, high level, according to Swedish guidelines (Cato 1997, Swedish EPA 2002, available at http:// www.environ.se). However, it is difficult to determine if these contaminants are considerably detrimental to the food source for these obligate heterotrophs, since they occur at sites characterized by pronounced stratification, which also limits diatom growth.

Nickel was positively correlated and scored high among the variables important for heterotrophic cyst abundance (Table 5C). Elevated concentrations of nickel in marine sediments are associated with production of stainless steel (Cato 1997). The highest concentration of nickel (24.7 $\mathrm{mg} \mathrm{kg}^{-1}$ ) was recorded at G2 (Stn 15). According to the Swedish EPA, sites exhibiting concentrations below $30 \mathrm{mg} \mathrm{kg}^{-1}$ are not considered to be affected by anthropogenic sources. Nickel is an essential micronutrient for microalgal growth (van den Hoek et al. 1995) and is involved in nitrogen uptake (Price \& Morel 1990). Hence, the concentrations present in the sediment probably favour the heterotrophic dinoflagellate taxa indirectly through their prey organisms.

In our data set from surface sediments, we could not confirm a higher relative abundance of heterotrophic dinoflagellate cysts from areas receiving high loads of industrial effluents, although this has been demonstrated from sediment cores in Norwegian fjords (Sætre et al. 1997, Thorsen \& Dale 1997). Sætre et al. (1997) showed that an elevated concentration of 6 trace metals correlated with a higher proportion of heterotrophic cysts and an overall decrease of the dinoflagellate cyst density. However, the concentrations of nickel, cadmium, zinc, and copper in their core from Frierfjord in Norway were 2- to 10-fold higher than the concentrations we registered from the surface sediment on the Swedish west coast.

Dinoflagellate cysts are generally smaller than $63 \mu \mathrm{m}$ in diameter; therefore, cysts settle out with the fine silt fraction in the sedimentation process. Hence, finergrained sediment provides samples richer in cysts than does coarser-grained sediment (Dale 1979, Goodman 
1987). The sediment samples investigated here were biased towards mud (average silt content 85.6\%, Table 2). Silt content had a low raking in the PLS analyses for total cysts and autotrophic taxa, whereas it scored higher in the PLS using heterotrophic abundance (Table 5C). From these analyses, it seems that silt content may be important to locate areas displaying high cyst densities, but only when other parameters, mentioned above, are optimized for dinoflagellate growth and cyst production. Silt content does not seem to have any explanatory importance in itself. This was also reported by Blanco (1995) who did not find any significant correlation between dinoflagellate cyst densities and mean grain size in coastal surface sediment samples from Galicia, NW Spain. In contrast, Wall et al. (1977) found that sedimentological factors were important in creating high-density cyst assemblages in offshore sediments.

The CCA screening pointed to mercury as an influential variable. It, together with summer total nitrogen, dominated CCA Axis 2 (Table 6, Fig. 5). Considerable effluxes of mercury are associated with crematoria, amalgam use, and chlorinealkali- and fluorescentlamp production (Cato 1997). Mercury is a nonessential element which is toxic (Okamoto et al. 1999). Inhibition of dinoflagellate growth has been reported in concentrations as low as $1 \mathrm{\mu g} \mathrm{l}^{-1}$ (Zingmark \& Miller 1975). Okamoto et al. (1999) recorded an $\mathrm{LC}_{50}$ concentration (allowing $50 \%$ survival) for cultured Lingulodinium polyedrum at $5 \mu \mathrm{g} \mathrm{l^{-1 }}$. They also observed enhanced temporal encystment (shedding of thecae) and altered bioluminescence when cultures were exposed to elevated concentrations of mercury, but no formation of true hypnozygotes were observed. In our sediments, highest concentrations were detected at Skalkorgarna (Stn 21) and Älvsborgsbron (Stn 22) (0.47 and $0.75 \mathrm{mg} \mathrm{kg}^{-1}$ sediment $\mathrm{dw}$, respectively). Accordingly, in the CCA biplot, these stations are located on the high end of the mercury gradient (Fig. 5A). In the species biplot, 6 out of the 13 dinoflagellate taxa are associated with high mercury levels. No values on the concentration of mercury in the water are available, but it is reasonable to assume that the levels are not high enough to inhibit dinoflagellate growth in the area, since reasonably high cyst concentrations were found at these stations. Moreover, mercury and total nitrogen are highly correlated (Table 7). The presence of the 6 dinoflagellate taxa in the lower left corner of the species biplot is perhaps more a consequence of higher nitrogen concentration and stratified water column, as discussed previously.

Of the 8 variables used in the CCA (Table 6), 3 had high VIFs. The high correlation between SS0 and WPO (Table 7) has a reasonable explanation since it is known that most of the $\mathrm{PO}_{4}{ }^{3-}$ available in the water column is generated through upwelling and not through river runoff (Selmer \& Rydberg 1993). Upwelling causes the water column to become mixed, hence, sea surface salinity is high. STN is inversely correlated to both WPO and SS0 (Table 7). Most of the nitrogen available for phytoplankton growth in these waters originates from river runoff (Selmer \& Rydberg 1993). At sites exposed to great runoff, surface salinity is low, the water is stratified, and upwelling is minimal, therefore, WPO and SS0 are low, while STN is high. Along the Swedish west coast it is reasonable to assume that the phenomena of upwelling and river discharge are more dependent on the site itself than the season. Hence, the correlations are strong between these parameters irrespective of season.

If the general sedimentation rate is unknown, it can be difficult to compare sites with respect to cyst densities, or to relate abundances to environmental factors. A site with a high sedimentation rate might yield low cyst density per unit weight, which could be interpreted as low dinoflagellate production (Matsuoka 1999, Cho \& Matsuoka 2001). Of the 19 investigated sites, sedimentation rates are known for only 4: Kosterfjord (Stn 3, $4.2 \mathrm{~mm} \mathrm{yr}^{-1}$ ), Fjällbacka (Stn 4, $1.9 \mathrm{~mm} \mathrm{yr}^{-1}$ ), G2 (Stn 15, $14 \mathrm{~mm} \mathrm{yr}^{-1}$ ), and Danafjord (Stn 20, $1.3 \mathrm{~mm} \mathrm{yr}^{-1}$ ) (Cato 1997). Thus, among the stations where data is available, the sedimentation rate varied by a factor of 10 . Consequently, the densities presented here should be treated with some caution. Predation is another factor that could contribute to the abundance of cysts and species distribution in the sediments (Persson 2000), but predation was not included in this study. Not much is known of the predation rate on dinoflagellate cysts in sediments, but Persson \& Rosenberg (2003) showed that deposit feeders (Abra nitida, Amphiura filiformis, Melinna cristata) selectively grazed on dinoflagellate cysts, and consequently changed the relative frequencies of species. In addition, there may be a selective pressure on some species in a particular chemical environment that could change species frequency or density (Karentz \& Smayda 1998). For instance, it has been demonstrated from sediment cores that different oxygen conditions not only influence the abundance of dinoflagellate cysts but also select for different species (Zonneveld et al. 1997). Oxygen concentration, measured just above the sediment surface, and various chemicals of anthropogenic origin in the sediments have been included in our multivariate models (Table 2). However, with the combining of several dinoflagellate species into broader taxa (Table 4) and, further, into autotrophs and heterotrophs, some information on selective preservation in different chemical environments might have been lost.

The 2 most frequently encountered dinoflagellate cysts in the sediment, Lingulodinium polyedrum and 
Protoceratium reticulatum, were rarely encountered in their planktonic form in the water column according to the monitoring data (Fig. 4A). Instead, non-cystforming dinoflagellates dominated the water column. L. polyedrum and $P$. reticulatum are thecate like other dinoflagellates belonging to the order Gonyaulacales, thus, they preserve well in different fixatives and should not be susceptible to misidentification. Therefore, this contrast between the plankton and the cyst records indicates that these species form comparatively small planktonic populations and are efficient cyst formers. Perhaps it is a widespread strategy for the cyst-forming dinoflagellates to exist for only a short period in the plankton, encyst quickly, and spend most of their time in the cyst stage. Not much is known about the efficiency of cyst formation by dinoflagellates. However, it is reported that approximately $50 \%$ of the planktonic population of $P$. reticulatum form cysts, whereas only $0.02 \%$ of the planktonic population of Gonyaulax digitale produce cysts (Dale 1976). Moreover, large cyst banks of the dominant species, $L$. polyedrum and $P$. reticulatum, are reported from several other temperate regions (Wall et al. 1977, Nehring 1997, Sætre et al. 1997). When only cyst-forming genera were considered, records of relative abundances in the plankton more closely matched those of the sediments (Fig. 4B).

\section{CONCLUSIONS}

From this study on the roles of various environmental factors affecting the distribution of dinoflagellate cysts in surface sediment along the Swedish west coast, the results suggest that there is not 1 single environmental factor responsible for density and species composition of the cyst bank. Rather, it is a set of variables. This set of variables was used to delineate 3 generalized habitats: fjord stations, coastal stations, and near-river stations (Fig. 6). Autotrophic taxa were favoured and present in largest numbers at sites where summer surface temperatures were higher (i.e. fjord stations and near-river stations), which afforded a potentially higher metabolic rate and a stratified water column. Nitrogen and phosphorus concentration and the absence of competitors in the form of diatoms were also crucial factors affecting autotrophic dinoflagellates. Lingulodinium polyedrum, the most common cyst type along the Swedish west coast, displayed high abundances in the fjord stations. Our results do not support previous interpretations of L. polyedrum as an indicator of eutrophicated areas. Heterotrophic dinoflagellate abundance was governed by the preferences of their prey, i.e. conditions favouring diatoms, and highest proportions were found at well-mixed coastal stations. An increased proportion of heterotrophic

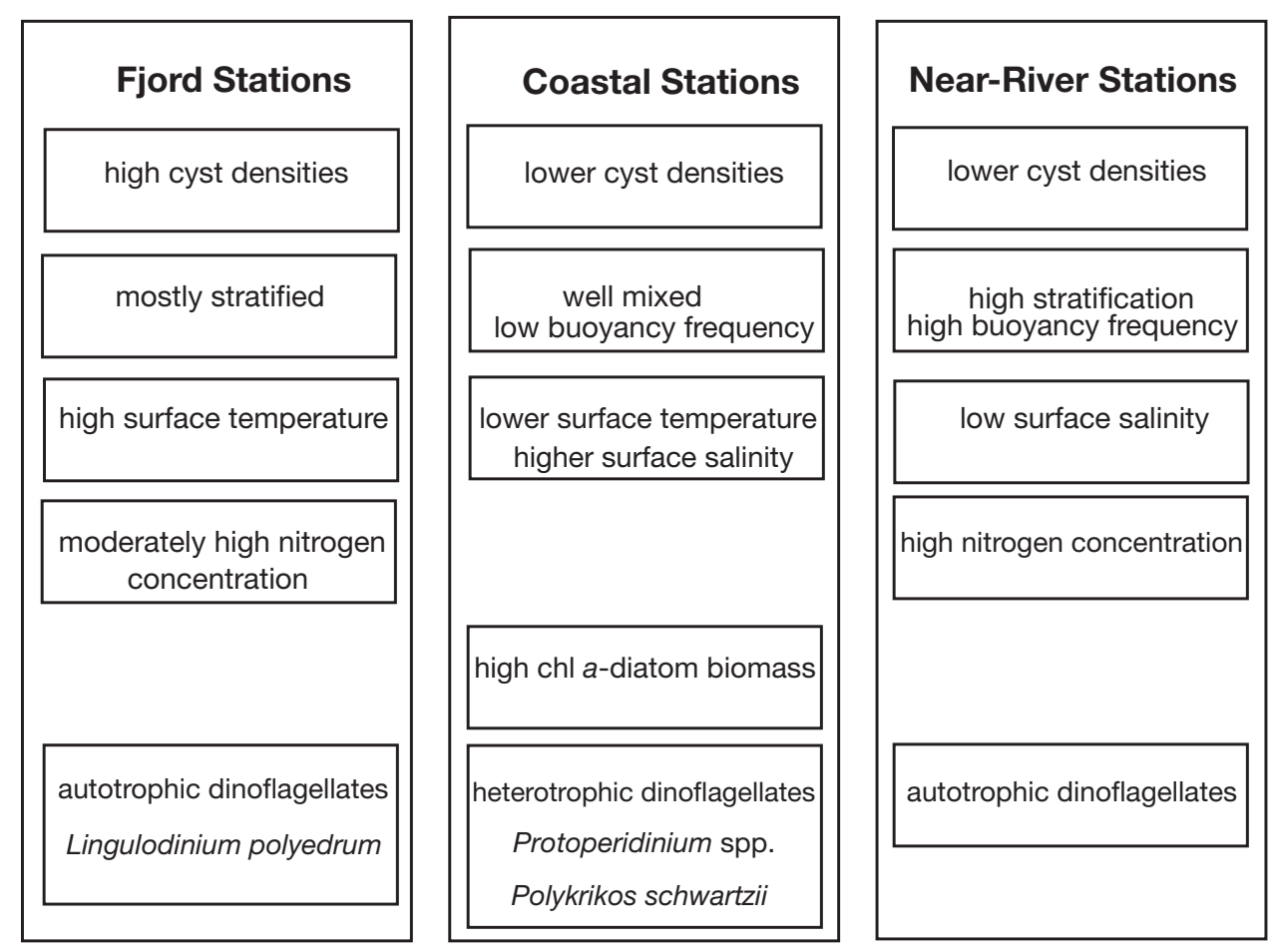

Fig. 6. Summary of the environmental factors influencing abundance and distribution of autotrophic and heterotrophic dinoflagellate cysts in 3 generalized habitats on the Swedish west coast 
dinoflagellate cysts reflected a favourable food supply rather than industrial activity. Autotrophic dinoflagellate cysts were proportionally more abundant at nearriver stations, with the exception of the cysts of the Diplopsalis group. Plankton data from 6 yr of monitoring shows that taxa common in the sediment often constituted a very minor part in the plankton community. However, their high numbers in the sediments indicate that the planktonic cells, although few, can be prolific cyst producers.

Acknowledgements. We thank the Water Quality Association of the Bohus Coast for providing us with the sediment samples. Professor I. Wallentinus, Marine Botany, Göteborg University, has critically reviewed and commented on the manuscript. This work has been supported by grants from the C. F. Lundström foundation, Lennanders stiftelse, and the Göteborg University Marine Research Centre (GMF).

\section{LITERATURE CITED}

Anderson DM (1998) Physiology and bloom dynamics of toxic Alexandrium species, with emphasis on life cycle transition. In: Anderson DM, Cembella AD, Hallegraeff GM (eds) The physiological ecology of harmful algal blooms. Springer-Verlag, Heidelberg, p 29-48

Archer SD, Leakey RJG, Burkill PH, Sleigh MA (1996) Microbial dynamics in coastal waters of East Antarctica: herbivory by heterotrophic dinoflagellates. Mar Ecol Prog Ser 139:239-255

Björk G, Liungman O, Rydberg L (2000) Net circulation and salinity variations in an open-ended Swedish fjord system. Estuaries 23:367-80

Blanco J (1995) The distribution of dinoflagellate cysts along the Galician (NW Spain) coast. J Plankton Res 17:283-302

Cato I (1997) Sedimentological investigations of the Bohus Coast 1995 and recent trends in coastal environmental sediment quality - a report from five trend-monitoring programmes. Geological Survey of Sweden, Uppsala

Cho HJ, Matsuoka K (2001) Distribution of dinoflagellate cysts in surface sediments from the Yellow Sea and East China Sea. Mar Micropaleontol 42:103-123

Dale B (1976) Cyst formation, sedimentation and preservation: factors affecting dinoflagellate assemblages in recent sediment from Trondheimsfjord, Norway. Rev Palaeobot Palynol 22:39-60

Dale B (1979) Collection, preparation, and identification of dinoflagellate resting cysts. In: Taylor FJR, Seliger $\mathrm{HH}$ (eds) Toxic dinoflagellate blooms. Elsevier, Amsterdam, p 443-452

Dale B (1983) Dinoflagellate resting cysts: 'benthic plankton'. In: Fryxell GA (ed) Survival strategies of the algae. Cambridge University Press, Cambridge, p 69-136

Dale B, Fjellså A (1994) Dinoflagellate cysts as paleoproductivity indicators: state of the art, potential, and limits. In: Zahn R, Pedersen TF, Kaminski MA, Labeyrie L (eds) Carbon cycling in the glacial ocean: constraints on the ocean's role in global change. Springer-Verlag, Berlin, p 521-537

Dale B, Thorsen TA, Fjellså A (1999) Dinoflagellate cysts as indicators of cultural eutrophication in the Oslofjord, Norway. Estuar Coastal Shelf Sci 48:371-382

Devillers R, de Vernal A (2000) Distribution of dinoflagellate cysts in surface sediment of the northern North Atlantic in relation to nutrient content and productivity in surface waters. Mar Geol 166:103-124

Dodge JD (1982) Marine dinoflagellates of the British Isles. Her Majesty's Stationery Office, London

Dodge JD (1989) Some revision of the family Gonyaulacaceae (Dinophyceae) based on scanning electron microscopy. Bot Mar 32:275-298

Drebes G (1974) Marines phytoplankton — eine Auswahl der Helgoländer Planktonalgen (Diatomeen, Peridineen). Georg Thieme Verlag, Stuttgart (in German)

Ellegaard M, Christensen NF, Moestrup Ø (1994) Dinoflagellate cysts from recent Danish marine sediment. Eur J Phycol 29:183-194

Ellegaard M, Lewis J, Harding I (2002) Cyst-theca relationship, life cycle, and effects of temperature and salinity on the cyst morphology of Gonyaulax baltica sp. nov. (Dinophyceae) from the Baltic Sea area. J Phycol 38:775-789

Ellegaard M, Daubjerg N, Rochon A, Lewis J, Harding I (2003) Morphological and LSU rDNA sequence variation within the Gonyaulax spinifera/Spiniferites-group (Dinophyceae) and proposal of two new combinations, Gonyaulax elongata comb. nov. and G. membranacea comb. nov. Phycologia 42(2):151-164

Eriksson L, Johansson E, Kettanneh-Wold N, Wold S (1999) Introduction to multi and megavariate data analysis using projection methods (PCA \& PLS). Umetrics, Umeå

Fritz L, Triemer RE (1985) A rapid simple technique utilizing calcofluor white M2R for the visualization of dinoflagellate thecal plates. J Phycol 21:662-664

Godhe A, Norén F, Kuylenstierna M, Ekberg C, Karlson B (2001) Relationship between planktonic dinoflagellate abundance, cyst recovered in sediment traps and environmental factors in the Gullmar Fjord, Sweden. J Plankton Res 23:923-938

Goodman DK (1987) Dinoflagellate cysts in ancient and modern sediments. In: Taylor FJR (ed) The biology of dinoflagellates. Blackwell Scientific Publications, Oxford, p 649-722

Hallegraeff GM (1995) Harmful algal blooms: a global overview. In: Hallegraeff GM, Anderson DM, Cembella $\mathrm{AD}$ (eds) Manual on harmful marine microalgae. IOC Manuals and Guides. UNESCO, Paris, p 1-22

Jeong HJ (1999) The ecological roles of heterotrophic dinoflagellates in marine planktonic community. J Eukaryot Microbiol 46:390-396

Johnson L, Hoagland K, Gretz M (1995) Effects of bromide and iodide on stalk secretion in the biofouling diatom Achnanthes longipes (Bacillariophyceae). J Phycol 31: 401-412

Karentz D, Smayda TJ (1984) Temperature and seasonal occurrence patterns of 30 dominant phytoplankton species in Narragansett Bay over a 22-year period (19591980). Mar Ecol Prog Ser 18:277-293

Karentz D, Smayda TJ (1998) Temporal patterns and variations in phytoplankton community organization and abundance in Narragansett Bay during 1959-1980. J Plankton Res 20:145-168

Kjœret AH, Naustvoll LJ, Paasche E (2000) Ecology of the heterotrophic dinoflagellate genus Protoperidinium in the inner Oslofjord (Norway). Sarsia 85:439-452

Lewis J, Harris A, Jones K, Edmonds R (1999) Long-term survival of marine planktonic diatoms and dinoflagellates in stored sediment samples. J Plankton Res 21:343-354

Lewis J, Rochon A, Ellegaard M, Mudie PJ, Harding I (2001) The cyst-theca relationship of Bitectatodinium tepikiense (Dinophyceae). Eur J Phycol 36:137-146 
Lindahl O (1995) Long term studies of primary phytoplankton production in the Gullmar fjord, Sweden. In: Skjoldal HR, Hopkins C, Erikstad KE, Leinaas HP (eds) Ecology of fjords and coastal waters. Elsevier Science, Amsterdam, p 105-112

Lindahl O, Belgrano A, Davidsson L, Hernroth B (1998) Primary production, climatic oscillation, and physio-chemical processes: the Gullmar Fjord time-series data set (1985-1996). ICES J Mar Sci 55:723-729

Loeblich AR II (1975) A seawater medium for dinoflagellates and the nutrition of Cachonnia niei. J Phycol 11:80-86

Matsuoka K (1999) Eutrophication process recorded in dinoflagellate cyst assemblages - a case of Yokohama Port, Tokyo Bay, Japan. Sci Tot Environ 231:17-35

McQuoid MR, Nordberg K (2003) The diatom Paralia sulcata as environmental indicator species in coastal sediments. Estuar Coastal Shelf Sci 56:339-354

McQuoid MR, Godhe A, Nordberg K (2002) Viability of phytoplankton resting stages in the sediments of a coastal Swedish fjord. Eur J Phycol 37:191-201

Nalewajko C, Lee K, Olaveson M (1995) Response of freshwater algae to inhibitory vanadium concentrations - the role of phosphorus. J Phycol 31:332-343

Naustvoll LJ (2000) Prey size and food preference in thecate heterotrophic dinoflagellates. Phycologia 39:187-198

Nehring S (1994) Spatial distribution of dinoflagellate resting cysts in recent sediments of Kiel Bight, Germany (Baltic Sea). Ophelia 39:137-158

Nehring S (1997) Dinoflagellate resting cysts from recent German coastal sediment. Bot Mar 40:307-324

Ohsawa N, Ogata Y, Okada N, Itoh N (2001) Physiological function of bromoperoxidase in the red marine alga, Corallina pilulifera: production of bromoform as an allelochemical and simultaneous elimination of hydrogen peroxide. Phytochem 58:683-692

Okamoto OK, Shao L, Hastings JW, Colepicolo P (1999) Acute and chronic effects of toxic metals on the viability, encystment and bioluminiscence in the dinoflagellate Gonyaulax polyedra. Comp Biochem Physiol C 123:75-83

Olseng CD, Naustvoll LJ, Paasche E (2002) Grazing by the heterotrophic dinoflagellate Protoperidinium steinii on a Ceratium bloom. Mar Ecol Prog Ser 225:161-167

Persson A (2000) Possible predation of cysts - a gap in the knowledge of dinoflagellate ecology? J Plankton Res 22: 803-809

Persson A, Rosenberg R (2001) Grazing on marine dinoflagellate cysts by benthic deposit feeding animals. In: Persson A (ed) On the ecology of cyst-producing dinoflagellates on the Swedish west coast. Paper V. Department of Marine Botany, Göteborg University

Persson A, Rosenberg R (2003) Impact of grazing and bioturbation of marine benthic deposit feeders on dinoflagellate cysts. Harmful Algae 2:43-50

Persson A, Godhe A, Karlson B (2000) Dinoflagellate cysts in recent sediments from the west coast of Sweden. Bot Mar 43:69-79

Editorial responsibility: Paul Harrison,

Kowloon, Hong Kong
Price NM, Morel FMM (1990) Cadmium and cobalt substitution for zinc in a marine diatom. Nature 344:658-660

Rodhe J (1987) The large scale circulation in the Skagerrak; interpretation of some observations. Tellus 39:245-253

Sætre MML, Dale B, Abdullah MI, Sætre GP (1997) Dinoflagellate cysts as potential indicators of industrial pollution in a Norwegian fjord. Mar Environ Res 44:167-189

Selmer JS, Rydberg L (1993) Effects of nutrient discharge by river water and waste on the nitrogen dynamics in the archipelago of Göteborg, Sweden. Mar Ecol Prog Ser 92: 119-133

Svansson A (1984) Hydrography of the Gullmar fjord. Hydrographic. Research 23, Meddelande från Havsfiskelab i Lysekil, Göteborg

Takayama H, Matsuoka K, Fukuyo Y (1998) A taxonomic study on Gyrodinium aureolum Hulburt (Dinophyceae) from morphological viewpoint based on materials collected in Japanese coastal waters. Bull Plankton Soc Jpn 45:9-19

Taylor FJR, Pollingher U (1987) Ecology of dinoflagellates. In: Taylor FJR (ed) The biology of dinoflagellates. Blackwell Scientific Publications, Oxford, p 398-529

ter Braak CFJ (1987-1992) CANOCO-a FORTRAN program for canonical community ordination. Microcomputer Power, New York

ter Braak CFJ, Prentice I (1988) A theory of gradient analysis. Adv Ecol Res 18:271-317

Thorsen TA, Dale B (1997) Dinoflagellate cysts as indicators of pollution and past climate in a Norwegian fjord. Holocene $7: 433-446$

Tomas C (1997) Identifying marine phytoplankton. Academic Press, San Diego

van den Hoek C, Mann DG, Jahns HM (1995) Algae-an introduction to phycology. Cambridge University Press, Cambridge

Versteegh GJM (1994) Recognition of cyclic and non-cyclic changes in the Mediterranean Pliocene-a palynological approach. Mar Micropaleontol 23:147-183

Wall D, Dale B, Lohmann GP, Smith WK (1977) The environmental and climatic distribution of dinoflagellate cysts in modern marine sediments from the regions in the north and south Atlantic Oceans and adjacent seas. Mar Micropaleontol 2:121-200

Wold S, Albano C, Dunn WJ III, Edlund U and 6 others (1984) Multivariate data analysis in chemistry. In: Kowalski BR (ed) Chemometrics - mathematics and statistics in chemistry. Reidel Publishing, Dordecht, p 1-79

Zingmark RG, Miller TG (1975) The effects of mercury on the photosynthesis and growth of estuarine and oceanic phytoplankton. In: Vernberg FJ (ed) Physiological ecology of estuarine organisms. University of South Carolina Press, Columbia, p 45-57

Zonneveld KAF, Versteegh GJM, Lange GJ (1997) Preservation of organic-walled dinoflagellate cysts in different oxygen regimes: a 10000 year natural experiment. Mar Micropaleontol 29:393-405

Submitted: August 6, 2002; Accepted: January 30, 2003 Proofs received from author(s): May 30, 2003 